\title{
CALL tO ACTION \\ How Programs in Three Cities Responded to the Prisoner Reentry Crisis
}

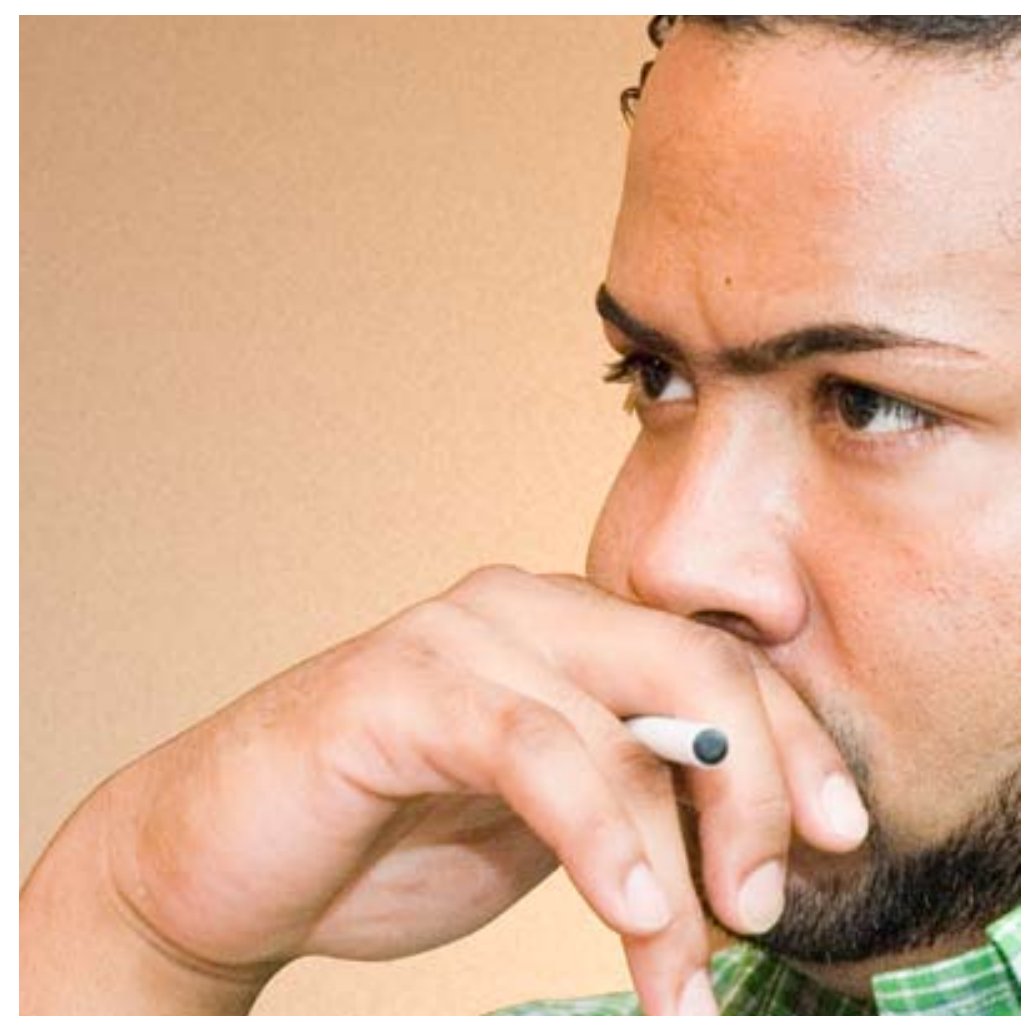

Paul VandeCarr 


\section{CALL tO ACTION \\ How Programs in three Cities Responded to the Prisoner Reentry Crisis}

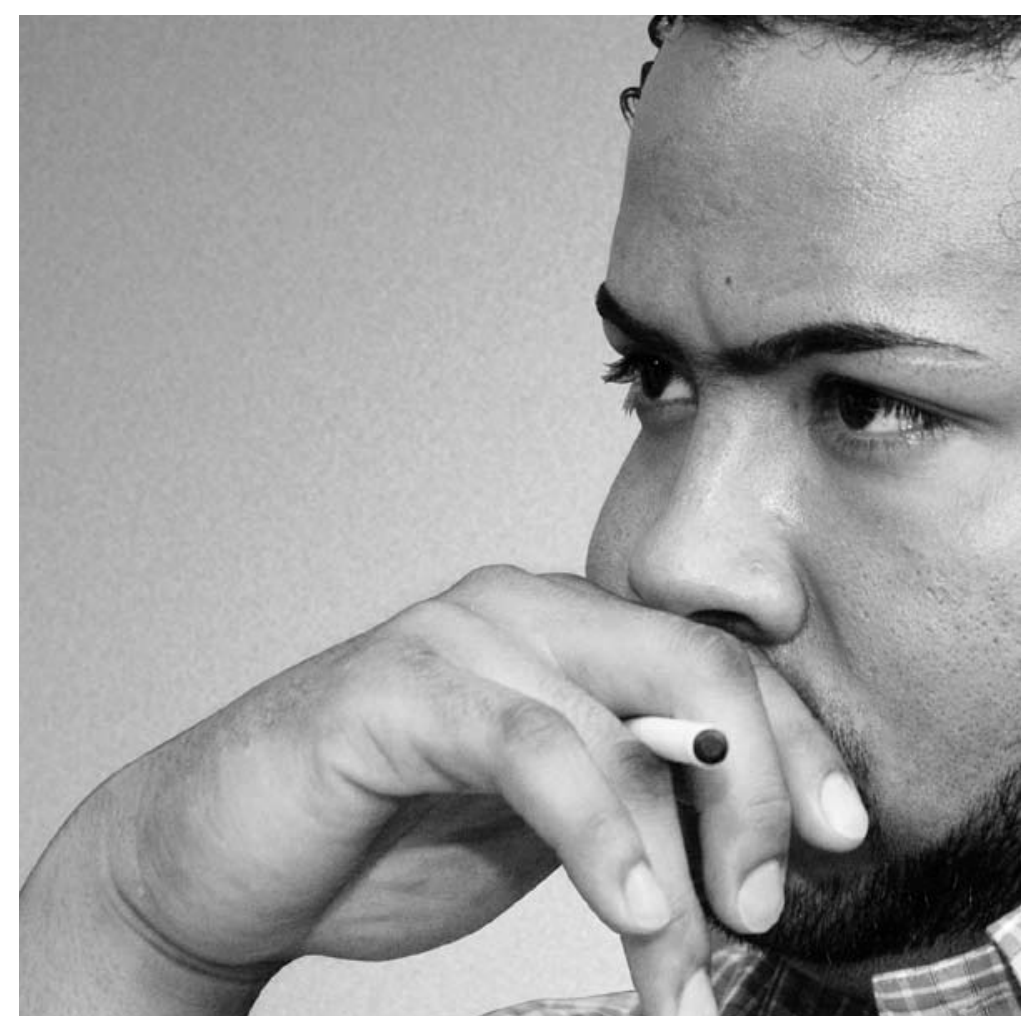

Paul VanDeCarr 
Public/Private Ventures is a national nonprofit organization that seeks to improve the effectiveness of social policies and programs. $\mathrm{P} / \mathrm{PV}$ designs, tests and studies initiatives that increase supports, skills and opportunities of residents of low-income communities; works with policymakers to see that the lessons and evidence produced are reflected in policy; and provides training, technical assistance and learning opportunities to practitioners based on documented effective practices.

\section{Board of Directors}

Matthew McGuire, Chair Vice President Ariel Capital Management, Inc.

Siobhan Nicolau, Chair Emeritus President

Hispanic Policy Development Project

Frederick A. Davie President Public/Private Ventures

Amalia Betanzos

Retired, President Wildcat Service Corporation

Yvonne Chan Principal Vaughn Learning Center

Jed Emerson Senior Fellow Generation Foundation, Generation Investment Management

The Honorable Renée Cardwell Hughes Judge, Court of Common Pleas The First Judicial District, Philadelphia, PA

Christine L. James-Brown President and CEO United Way International

John A. Mayer, Jr. Retired, Chief Financial Officer J.P. Morgan E Co.

Maurice Lim Miller Director Family Independence Initiative

Anne Hodges Morgan Consultant to Foundations

Marion Pines Senior Fellow Institute for Policy Studies Johns Hopkins University

Clayton S. Rose Retired, Head of Investment Banking J.P. Morgan $\mathcal{E} \mathrm{Co}$

Cay Stratton Director

National Employment Panel London, U.K.

Sudhir Venkatesh Associate Professor Columbia University

William Julius Wilson Lewis P. and Linda L. Geyser University Professor

Harvard University
Research Advisory Committee

Jacquelynne S. Eccles, Chair University of Michigan

Ronald Ferguson Kennedy School of Government

Robinson Hollister Swarthmore College

Alan Krueger Princeton University

Reed Larson University of Illinois

Milbrey McLaughlin Stanford University

Katherine S. Newman Kennedy School of Government

Laurence Steinberg Temple University

Tom Weisner UCLA 


\section{FOREWORD}

Call to Action provides a vivid illustration of how individuals, community organizations, faith institutions, businesses and officials in cities across the country have mobilized to build partnerships that address escalating numbers of ex-prisoners returning to their communities. Many returnees have no viable job prospects, no social supports and no access to services; two thirds will be rearrested and almost half will return to prison within three years. This cycling in and out of prison has devastating consequences not just for the prisoners themselves, but also for their families and neighborhoods.

The three communities highlighted in this report, Jacksonville, FL; Memphis, TN; and Washington, DC, were pioneers in responding to the nation's prisoner reentry crisis. They developed impressive programs and eventually joined P/PV's Ready4Work initiative, a three-year national demonstration funded by the US Departments of Labor and Justice and the Annie E. Casey and Ford foundations to test the capacity of local faithand community-based groups to provide effective services to ex-prisoners-primarily employment services, case management and mentoring. Early results from Ready4Work are extremely promising, with recidivism rates for participants that are 50 percent below the national average. Without the groundbreaking work of leaders in communities like Jacksonville, Memphis and Washington, Ready4Work's achievements would have been impossible-in turn, by participating in the larger initiative, local sites gained an organizing framework, resources and a method for gauging progress and ensuring success in ways not previously experienced.

Despite the progress that's been made, important work remains. The collective experience of Ready4Work sites highlights the need for more collective and integrated approaches to prisoner reentry-across cities, regions and states; public and private resources and funding streams need to be redirected, pooled and put to use in more strategic, cost-effective and outcomes-driven efforts. Research findings that show promise for specific program strategies must be at the center of these partnerships, guiding dialogue as well as the design of initiatives and program evaluations.

Understanding prisoner reentry from the perspective of the communities that are most affected is a good step toward advancing these efforts. We hope this report-in concert with several others on Ready4Work that are forthcoming — contributes to a deeper understanding of what makes for successful prisoner reentry. This work is critical for the men and women, families and communities affected by high rates of incarceration and recidivism, and should serve as a beacon to public and private decision-makers searching for effective solutions.

Frederick A. Davie

President
Renata Cobbs Fletcher

Vice President for Public Policy and Community Partnerships 
CALL TO ACTION 


\section{ACKNOWLEDGMENTS}

The author wishes to thank all of those who shared their experiences and insights about reentry work.

In Jacksonville, FL, Kevin Gay, Rev. Garland Scott and Paula Adkins-Jamison graciously told the story of Operation New Hope. Rev. Robert Brown, Marie Carter and Joyce Johnson also helped with an understanding of the program's background. In the Jacksonville sheriff's office, thanks go to Chief Stephanie Sloan-Butler, Officer Lisa Love and Lorna Jones-Stutson.

In Memphis, TN, the staff of the Second Chance program were generous with their time and stories. Thanks especially to Yalanda McFadgon and Terrence Johnson. City officials also contributed, including Mayor Willie Herenton, Chief Administrative Officer Keith McGee and Memphis Area Transit Authority General Manager William Hudson, Jr. Judge J.C. McLin, Verlon Harp and Isaac Garrett also shared insights.

In Washington, DC, many thanks to the staffs of East of the River Clergy-PoliceCommunity Partnership (ERCPCP) and the Court Services and Offender Supervision Agency (CSOSA). At CSOSA, Cedric Hendricks was especially informative. At ERCPCP, Rev. Donald Isaac and Julia Irving were thoughtful and responsive. Rev. Anthony Motley was likewise very giving and helpful. Thanks also to Jesus Hidalgo of Miller \& Long Concrete Construction, Rev. Lula Bell and Kenneth Glover for speaking about their experiences.

At Public/Private Ventures, Fred Davie was the primary force behind the Ready4Work prisoner reentry initiative and commissioned this report. Samuel Harrell provided invaluable direction, and Gayle Preston was tremendously helpful with the logistics surrounding the report's research. Renata Cobbs Fletcher and Chelsea Farley offered useful feedback and managed the final publication process, with graphic design provided by Penelope Malish.

Many thanks to the US Departments of Labor and Justice and to the Annie E. Casey and Ford foundations for their generous support of the Ready4Work prisoner reentry initiative. 
CALL TO ACTION 


\title{
CONTENTS
}

\author{
INTRODUCTION . . . . . . . . . . 1 \\ Jacksonville CASE Study ........ 5 \\ Memphis Case Study.......... 15 \\ Washington Case Study. . . . . . 25 \\ ConCLUSION . . . . . . . . . . 37 \\ ENDNOTES. . . . . . . . . . . 47
}




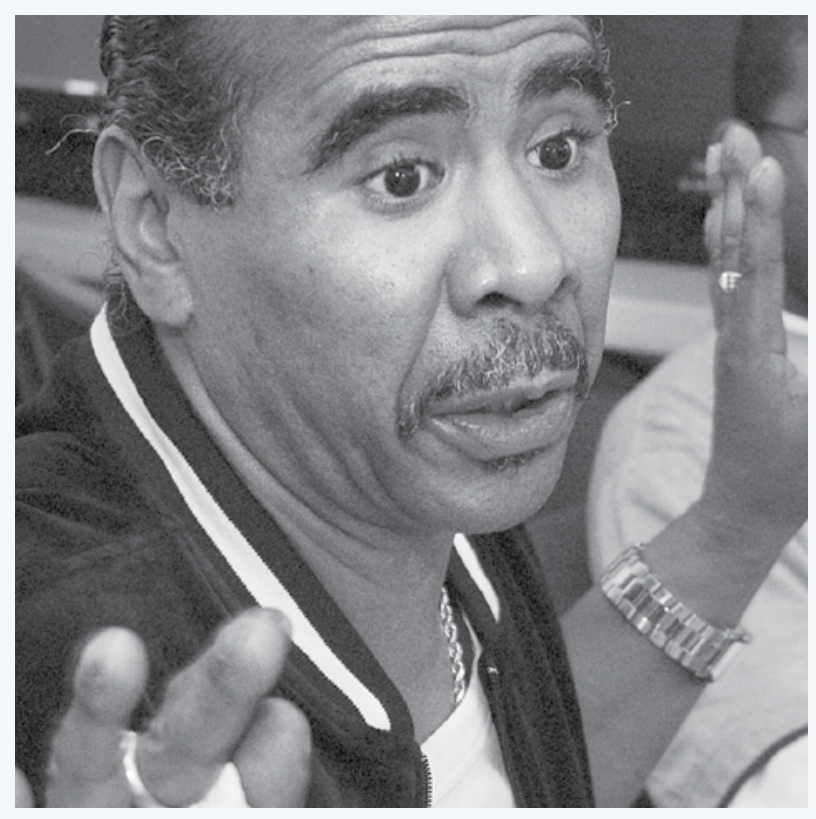




\title{
INTRODUCTION
}

\author{
Getting Out
}

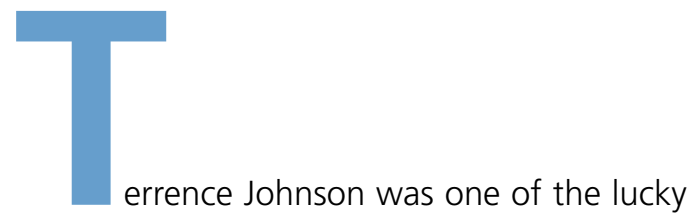

ones. After serving eight months in a halfway house (and then home confinement) on a felony wire-fraud conviction, he was back in the job market in Memphis, TN. He was still young, he had some college education and he did not have the stigma or the disadvantage of having served time in prison.

But for the life of him, he could not find a job.

"At every job interview, it was the same thing," he explains. "We'd go through all the usual questions. And I'm thinking that people are interested in me and what I can offer. But then the question about my conviction always comes up. And so I'm spilling my guts, saying, 'This is what I've done, and I want to work.' I want to be truthful, but I don't want them to think I'm a bad person and a criminal and a barbarian, and belittle me. And then there's the inevitable letdown. So you've got these voices going on in your head. It was instilled in me to second-guess myself."

In the two and a half years after completing his sentence, Johnson was able to cobble together eight months of work. At long last, in 2001, the Second Chance program was founded to help ex-prisoners in Shelby County, where Memphis is located, to find jobs. Johnson ended up working for the program itself, and after a year of successful employment, he was in the first graduating class, in 2002.

It was a milestone year for Johnson, as well as for the criminal justice system. That year, 2002, the number of people incarcerated in the United States hit the two million mark. ${ }^{1}$ As the prison population soared, so too did the number of prisoners transitioning back to life on the outside, to more than 600,000 per year. ${ }^{2}$ Multiply the number of returnees by the severity of the problems they had in reintegrating - as well as the problems they caused by recidivating - and it amounted to a bona fide crisis.

Fortunately, the movement to reintegrate ex-prisoners back into their communities got a boost that same year with the birth of Ready4Work, a national demonstration project to connect ex-prisoners with mentors and jobs. The project was funded principally by the US Department of Labor, as well as by the US Department of Justice, the Annie E. Casey Foundation, the Ford Foundation and Public/Private Ventures (P/PV), which also administered the program. 
Ready4Work brought together efforts that local groups had been making for years. Homegrown programs from Memphis to Oakland to Boston to Cincinnati had been born of the passion and dedication of a few individuals who recognized a need that was growing around the nation. Husbands, sisters, brothers, sons, fathers, mothers, fellow parishioners, coworkers, old friends and neighbors were getting out of prison and needed help readjusting to life. Perhaps most urgently, they needed jobs.

"A felony conviction is like a life sentence," says Second Chance executive director Yalanda McFadgon. "You've paid your debt to society, but you're marked, and no one will give you a job." The challenges extend far beyond employers' preconceptions. McFadgon ticks off the many other difficulties that ex-prisoners face, ones who are not as fortunate as Johnson and have served prison time: Broken family ties, no social support system, homelessness, no transportation to get to and from the job they can't even obtain, drug and alcohol addiction, HIVIAIDS, mental health problems, low literacy levels, lack of formal education, unfamiliarity with the world of work, no money to buy work clothes, and payments-restitution, probation fees, child support-that make it more difficult to get a foothold.

Little wonder that few ex-prisoners lucky enough to get a living-wage job can actually keep it. Whether succumbing to old habits or committing crimes to survive, many of them will recidivate. A 2002 study by the Bureau of Justice Statistics shows that two thirds of returnees are rearrested within three years of their release from prison. ${ }^{3}$ And so the crime rate continues to rise, victims and their families suffer the consequences of those crimes, communities become less safe, the social service and criminal justice systems become more strained, ex-prisoners go back to prison and leave their families at greater risk of poverty and other negative outcomes, and taxpayers foot the bill to incarcerate them.

The reentry crisis affects some individuals and communities more directly than others, but its ramifications are so far-reaching as to leave virtually no American untouched. Before the advent of Ready4Work, which was designed to be a largescale and systematic response, most programs addressing the reentry crisis were small and local. The problem for those communities, then, was how to help ex-prisoners reenter society successfully, and to stay.

\section{Rationale and Organization of the Report}

This report is the story of how programs in three cities responded to the reentry crisis, before they became part of the Ready4Work initiative. In Jacksonville, FL, a white businessman and a black pastor put ex-prisoners and others to work building low-income housing through their Operation New Hope. In Memphis, the city-funded Second Chance program prepared ex-prisoners for work and recruited employers to hire them. And in Washington, DC, the East of the River Clergy-Police-Community Partnership paired volunteer mentors from churches with ex-prisoners and connected the latter with willing employers. 
These three programs - as well as the other sites that constitute the initiative-were selected for inclusion in Ready4Work for a variety of factors. ${ }^{4}$ Chief among them was their proven ability to serve high-risk individuals and a history of collaborative work in communities with a substantial number of ex-prisoners. In shaping the initiative, P/PV and the Department of Labor strove for geographic diversity and sought out cities where the local business and criminal justice sectors were expressly willing to participate.

Based on written materials and interviews with staff, supporters and participants, this report chronicles the genesis and growth of the programs in Jacksonville, Memphis and Washington, up through when they received Ready4Work funding. This report treats the three programs in turn, and a conclusion discusses lessons learned from their early experiences. Three previous P/PV reports cover the creation and early implementation of Ready4Work, emerging best practices and early outcomes. ${ }^{5}$ This report documents their pre-Ready4Work experiences, according to the logic that those experiences can still instruct and inspire today. The three programs that are profiled here represent a diverse set of local contexts and responses to the reentry problem. The innovation and commitment they displayed in building their programs-before Ready4Work was implemented-can still be valuable for organizations across the country that are striving to develop or expand their own reentry work.

Indeed, the efforts of these and other individual programs made way for the formation of Ready4Work. And Ready4Work, in turn, played a significant role in President Bush's decision to create the Prisoner Reentry Initiative. The federal government's concern about the reentry crisis has arisen in good part thanks to the small voice with which these programs began speaking years ago.

Program staff in all three cities felt called to do this work. In Washington, Rev. Donald Isaac says, "Most faiths indicate that we are obligated to visit those in prison, to provide for the homeless, to help the needy, to serve the least and the last. Men and women returning from incarceration clearly represent the least, the last and the lost."

The faith that fuelled these program leaders also challenged the longstanding belief that "nothing works" to rehabilitate ex-prisoners and cut back on recidivism. Their faith compelled them to try. And the product of their deeds - the programs they created and that are documented here-may provide evidence that something can indeed be done to ease this social and moral crisis. 


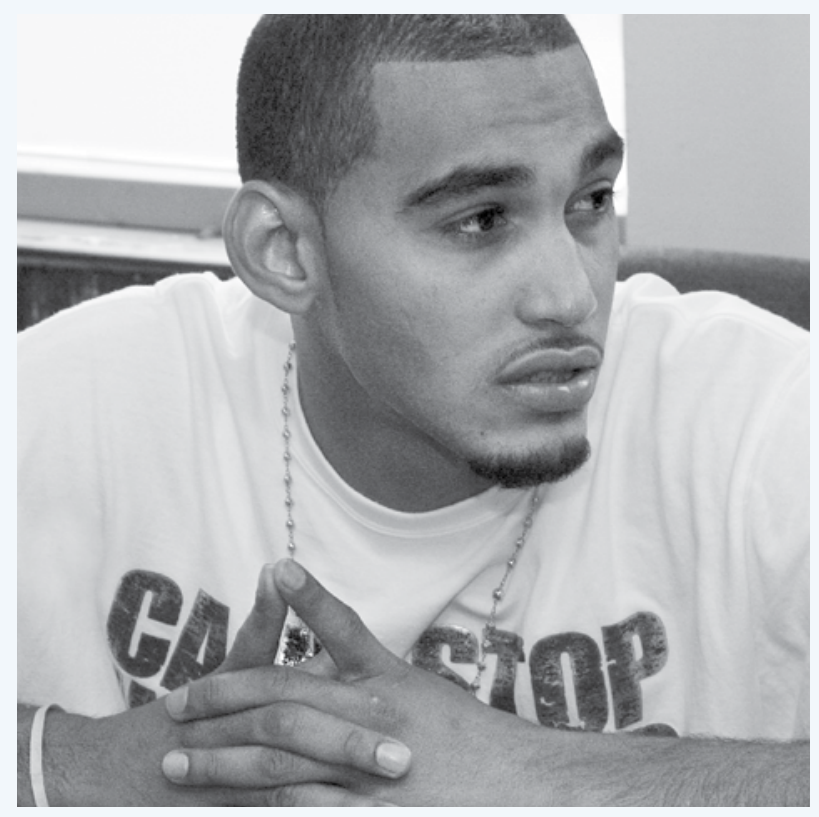




\title{
JACKSONVILLE CASE Study
}

\author{
A Journey in PROgRess
}

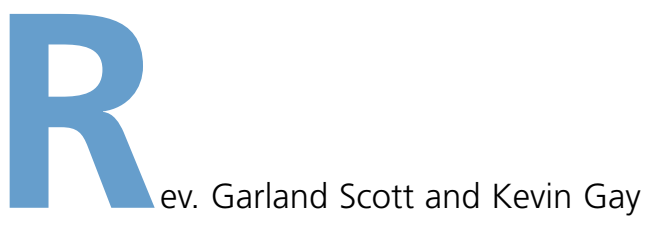

had traveled far-literally and figuratively — to get to the White House for what they thought was a large group meet-and-greet with President Bush. The two were being singled out for putting ex-prisoners and others to work rehabilitating homes in Jacksonville. Their "Operation New Hope"—founded by Gay and later supported by Scott-was now gaining national recognition.

They were let into the White House, then asked to wait in the Roosevelt Room with several other people, including Secretary of Labor Elaine Chao. As the meeting time approached and no one else showed up, they began to wonder. In fact, they began to get very nervous. "Garland asked where all the people were," Gay recalls, "and that's when we realized it was just us! Then Garland said, 'Only in the United States can you go from being a gangster to getting ready to meet the president!'"

Indeed, the meeting was a milestone on the journey of faith in action for the duo that had become locally known as "Ebony and Ivory," a black minister and a white businessman whose program turned lives around.

Operation New Hope started by employing "the homeless and destitute." There were doubtless some ex-prisoners among them, considering that 49,000 people were being released from jail or prison every year to live in Duval County, where Jacksonville is located. But their presence and their needs as ex-prisoners were only known to Operation New Hope if they themselves disclosed it. In this way, the reentry crisis was invisible. Ex-prisoners had a specific set of needs. Some of those needs, like transportation and health care, were common to homeless and poor people. But others, like voting rights restoration and being barred from certain types of employment, were specific to ex-prisoners. It was this constellation of needs - transportation and health care and voting-rights restoration and employability and so on-that was unique. Once Operation New Hope recognized ex-prisoners as a distinct population, it became clearer how best to support them in their life after incarceration. But all of this would come later. 


\section{FINDING A MISSION}

Kevin Gay had wanted to be a preacher since he was a child. Among the last things he expected was to end up in the insurance business, where he spent 15 years insuring contractors and homebuilders' associations around the country. His interest in the ministry endured throughout his time in business, and he went out on two missions, one to Mexico and one to Nicaragua. But it wasn't until 1998 that the spark came to truly ignite his work in the Jacksonville community.

That spark came in the form of Rev. Mother Davette Turk, the pastor of Fresh Ministries in Jacksonville, and a person whom Gay describes as "a wonderful lady, a fireball, a civil rights worker. She'd been a Catholic nun for 25 years, a very proactive person who brought together resources to make things happen. She asked me, 'When are you going to quit talking about your calling and start doing something about it?'"

Gay's religious faith made him committed to serving the poor, and his professional experience gave him a knowledge of construction. He had come to understand how homes-building, restoring and occupying them-could transform people's lives for the better. Having crisscrossed the country for years, seeing houses and neighborhoods revitalized, he was ready to take the power home.

\section{A One-Time Hollywood Falls Into DisRepair}

The Springfield district of Jacksonville, where Operation New Hope is based, hadn't always needed quite so much help. Whole swaths of Jacksonville were devastated by the Great Fire of 1901, but Springfield was spared major damage thanks to a citizens' bucket brigade and a natural firebreak at nearby Hogan's Creek. Many people burned out of their downtown homes sought refuge in Springfield, and there began a 20-year boom for the neighborhood. Scores of new homes were built, mostly in the bungalow and prairie styles, but many in the more ornate Queen Anne and colonial revival styles. The district was even somewhat of a little Hollywood before there was a Hollywood. For a time it was home to numerous major motion-picture studios, including one designed by the locally famous architect Henry J. Klutho. Charlie Chaplin and Laurel and Hardy lived in the building where Operation New Hope would one day have its offices.

But the heyday could only last so long. Springfield's star began to fade in the 1930s as film studios, drawn by tax breaks and other incentives, moved to California. Large segments of the population also fled to the suburbs in the following decades. By the 1950s, the district was, according to one newspaper report, proclaimed dead. ${ }^{6}$ Others recognized a familiar pattern: an African American influx, white flight, official neglect, and the poverty and crime that so often results.

Poorly as the neighborhood might have fared economically, however, preservationists recalled its storied past and still beautiful homes. Through their efforts, Springfield was declared a national historic district in 1987. The new status made way for greater interest and investment in the neighborhood. Mayor John Delaney and Sheriff Nat Glover, both elected in 1995, dedicated more money and police presence to the area. 
The city's planning department launched a revitalization effort. As official interest in the area increased, so did property values, as much as doubling in the few years before the centennial of the Great Fire. ${ }^{7}$ In spite of the resurgence, the neighborhood still needed work. Kevin Gay estimates that at the approach of the new millennium, more than half of the neighborhood's roughly 1,800 structures needed major repairs. And more than a few of its residents needed decent, affordable housing.

\section{RESTORING HOMES}

Ideas had begun to gel in Kevin Gay's mind. He was committed to serving the poor and had experience in the housing industry. A neighborhood in his own backyard needed help. And so in 1998 he formed a community development corporation, Operation New Hope, as a subsidiary of Fresh Ministries, which gave a start-up loan to the project. It effectively began work in 1999 and incorporated as a nonprofit later that same year.

The goal was to build affordable housing for low-income people in the Springfield district. From his experience in the insurance industry, Gay knew that community development often meant gentrification, but he was committed to not pricing poor people out of their own neighborhood. Operation New Hope would buy dilapidated homes from their owners, gut them out and rehabilitate them, and sell them with public subsidies to low-income residents. He would spread the news through community fairs, churches and word of mouth.

"We built one place the first year, then three the next year," Gay says. The program was small, and progress was gradual. Funding was limited to what Gay could gather on behalf of Fresh Ministries. Staff consisted of Gay as executive director, an office manager named Paula Adkins-Jamison and a rotating AmeriCorps volunteer. The houses were framed by people recruited from a local substance-abuse recovery program, and professional contractors were hired to supervise the construction and do the more skilled work.

"One day in 2000, I was sitting on the steps of one of Operation New Hope's buildings," Gay recalls. "I was with my brother-in-law, who had built my house, by the way. There was a prostitute walking on the other side of the street, someone maybe doing a drug deal. And my brother-in-law said to me, 'It will be hard for you to develop the value of this property without restoring the value of the community.'" His brother-inlaw's words pointed to a far greater mandate.

In the meantime, Gay had more immediate matters to tend to. Theft plagued Operation New Hope worksites. Ladders, tools and other items would routinely go missing. He could scarcely build housing, let alone restore the value of the community, if he had no equipment. So Gay implemented what turned out to be "not such a great idea after all" - to lock those items in a trailer on the site. "What happened was, now people would just steal the whole trailer!" Gay explains. He was at wit's end, when one day, Rev. Garland Scott, a local minister he'd been introduced to the previous year by Rev. Turk, asked him what would be another fateful question: "Are you ready to listen?" 


\section{RESTORING LIVES}

Scott says he can identify with the people Operation New Hope serves. At age 12, he was badly beaten in a riot in New York City and later joined a gang. "I swore I would never get beaten up like that again," he says. He spent the next seven years training other gang members, until finally, at age 20 , the threats on his life were more than he could handle and he moved to Florida for refuge. He worked as a truck driver in Baldwin, and later in the postal service in Jacksonville. Then he got religion and began ministering. 8

In 1993, he joined the staff of a mostly white mega-church called New Life Christian Fellowship, where he worked to expand its minority membership and services to people of color. "After a while I got known as 'the black pastor at New Life that can help you,'" he recalls. Then in 1998, with the financial and spiritual support of New Life, Rev. Scott launched City Center Ministries. The new congregation was in the Springfield district and facilitated job opportunities for parishioners, among whom were ex-prisoners, homeless people and drug addicts. ${ }^{9}$

\section{A Meeting of Minds}

"He restores the houses," Scott would later say of Gay. "I restore the lives."10 The marriage of minds - and program models—seemed so natural as to be almost preordained. Scott proposed that Gay hire some of the neighborhood residents to work on the houses. That way, he suggested, the Operation New Hope buildings would no longer be marked for theft. "I hired a couple guys from right around the work sites, and sure enough, the stealing stopped," Gay remembers. "That galvanized in me the power of a job."

Thanks to a simple change in model, Operation New Hope was now more fully integrated into the community: They would hire local low-income people to rehabilitate houses for other local low-income people. The mission of the program would accommodate not just the people who occupied the houses but those who built them. Gay's emphasis was now to employ "the homeless and destitute." Ex-prisoners were not yet an explicit part of the picture, though as he later discovered, there were a good many among the people he hired.

The problem of theft had been solved, but some troubling issues remained. Workers were being paid $\$ 7.50$ per hour at the time, well above the minimum wage. And yet some participants were falling through the cracks. "A guy might come to work, start off strong, but then a month later he'd disappear. Another guy might miss a few days and not offer an explanation," says Gay. "We started to dig deeper, and found that a lot of these guys were getting their wages garnished 50 percent or more for child support. They would go under the radar and get an under-the-table job so they didn't have to pay child support." (Operation New Hope did not address this problem until after Ready4Work funding began, at which point it started helping participants negotiate their child-support payments and schedule in accordance with their living expenses.) Gay added, "Transportation is key, because this is a huge city. It took us a while to learn 


\section{"Services For Ex-Offenders" Study}

"Ex-offenders are convicted perpetrators of crime. They are also individuals with human needs and, after release from incarceration, members of the community." So began a 2001 report by the nonpartisan Jacksonville Community Council Inc. (JCCI). "Society pays a heavy price for crimes committed and for the incarceration of offenders. That price multiplies if offenders commit crimes again. Therefore, the community has a strong interest in assisting ex-offenders to become successful members of the community, free of crime, living stable and productive lives." 11

The study was spearheaded by Jacksonville's corrections director at the time, John Rutherford, who recognized a burgeoning crisis and sought to apply his belief in rehabilitation-not just punishmentto relieve it. The report identified the needs of the roughly 49,000 people released every year from jail or prison to Duval County, where Jacksonville is located (1,200 from state prisons, the rest from the Duval County jail). Covering such areas as health, addiction, HIV/AIDS, transportation, housing, literacy and education, legal assistance, personal assistance and employment, these needs made up a web of interrelated issues. An ex-prisoner could not get to work without transportation, was less likely to be able to find a job without basic literacy skills or keep a job without viable housing. Ultimately, the report warned, "The consequence of not securing productive, well-paying work may be that some exoffenders revert to criminal 'job' skills they already know, such as theft and drug-dealing."

Existing services were limited at the time of the report, in employment as in other areas, and even those were available only to a small portion of offenders while still incarcerated. The study made recommendations on how to fulfill these needs. Fortunately, Operation New Hope was interested in doing just that.

that we had to plug holes in the dam." Some of those holes were the very same needs that would later be identified in a 2001 report by the Jacksonville Community Council - transportation, substance-abuse treatment, education and community support (see text box above). People who were not getting these needs met could not work and would slip back into drugs, crime or other self-destructive behaviors.

There were few places ex-prisoners could go for such help in 2001. Various programs existed in Jacksonville to help residents find housing, work and counseling. Some offered referrals but no support services, and very few were tailored specifically to the needs of ex-prisoners. The network of services was too complicated and difficult for most people to navigate, and there was no one single place that coordinated the various services ex-prisoners and other indigent people needed.

\section{FILLING THE GAPS}

Operation New Hope did not yet have the capacity to help its employees get back on their feet in the way they would have liked. Still, now working together more closely, Gay and Scott devised some mechanisms for addressing these problems, including informal mentoring and linking pay to services. 
Rev. Scott, Rev. Turk and her husband, Father Richard Turk, would go to the worksites to talk with the men there. While not part of a formal mentoring program, these chats kept workers in contact with a stable source of spiritual and practical counsel, as well as substance-abuse rehabilitation services. Kevin Gay, who had counseled recovering substance abusers for the previous five years, in what he called "a sort of personal ministry," also acted as an informal mentor. Only some of the workers were people of faith, says Gay, "but in any case we don't lead in by banging somebody over the head with a Bible. If we're doing our work, then our faith is going to come through."

During the first years of the program, Operation New Hope would deliver paychecks directly to the workers at their homes or the worksites. But in 2001, it was decided that workers would have to come pick up their checks at the offices of Rev. Scott's nearby City Center Ministries. "It was another way to reach them so we could understand what their needs were and how we could meet them," says Gay. Similarly, for those workers not ready to hold a job because of substance abuse, "I could get them hooked in at one of the treatment facilities we started working with and guarantee them a job on the other end."

These measures pointed toward an increasingly holistic view of the person and the community, says Gay. "We've always tried to develop a relationship first. In real estate, it's location, location, location. With us, it's relationship, relationship, relationship."

\section{BUILding THE PARTNERShIP FROM WithIN}

That principle applied no less to Gay and Scott than it did to the program and its clients. They lent one another their respective strengths. Gay brought business acumen and relationships in the business community. Scott educated Gay on the local African American community's needs and gave him credibility and contacts.

The pair had to continually develop their own working relationship for the organization to succeed. For his part, Scott says that the two needed to expect, respect and resolve differences between themselves. Some differences of opinion arose over their roles. As a pastor, Scott's emphasis was on the mission of the organization, and he did not want the quest for funds to interfere with it. A businessman by trade, Gay was interested in developing the organization's work. Though each had experience in both finance and faith, the challenge was how to balance those two directives. They worked to clarify their roles in the organization and the purpose of the organization itself.

They also had to spend some social capital on one another. Scott says, "I took some blows in the faith community. Some people would say, 'Get rid of Operation New Hope; get rid of the white guy." 12 In order to win over skeptics, the duo had to be persistent and reliable and work together. 


\section{BUILDINg PROgRAM CAPACITY}

The program was growing bigger and stronger. Operation New Hope was now managing a half dozen or more workers from the community at any given time and rehabilitating several houses for low-income area families. Gay had developed partnerships with a variety of local businesses_-such as a car dealership and Blue Cross Blue Shield-that, in exchange for their support, received good publicity and state and federal tax credits.

And yet Gay could hardly help but wonder how the enterprise might grow to serve more people more effectively. How could Operation New Hope-like the large-scale efforts he had seen in his days in the insurance business-become more self-sustaining? His businessman's mind went to work.

His answer was to create a nonprofit construction company operating under the auspices of Operation New Hope. This allowed the program to more easily manage its workforce development and to generate revenue in support of any wraparound services it could provide.

Ingenious as the scheme may have been in theory, Gay now calls it "naïve." Building low-income housing did not generate anywhere near enough income to fully finance the organization, but it did complement the funds raised from other sources.

"We hired 8, 10, 12, maybe 15 people under the auspices of the nonprofit construction company," Gay recollects. "At the same time, the chaplain's office at the Jacksonville jail heard about us and sent folks to us to see about jobs. We didn't prescreen people and didn't care if they had a felony record, and so it turns out we were hiring people, maybe 75 percent of whom had been arrested before or had records."

By the end of 2001, Operation New Hope had developed a more complex working model: a nonprofit construction company that delivered quality housing to low-income residents, and jobs and informal mentoring to people coming off the streets and many, as it happened, out of jail.

Gay began to see the benefits of a closer partnership with people in corrections. $\mathrm{JCCl}$ had issued its report on Services for Ex-Offenders at the instigation of then-corrections director John Rutherford. A critical mass of corrections staff supported his vision of rehabilitation rather than just punishment. Among them was longtime corrections worker Lorna Jones-Stutson. She says, "It's only by grace that I'm on this side of the table instead of that side of the table [in jail]. My background is in social work. This job is my ministry." It wasn't until the following year that a formal collaboration began, but the two parties were already beginning to recognize a clear truth. As Rutherford's successor, Stephanie Sloan-Butler puts it, "The greatest thing we need from Operation New Hope is the commitment to help us fulfill our mission."

The program was successful as far as it went. But some funders expressed concern that it didn't go far enough. They were frustrated at the lack of a viable development plan for the program's various components. There was neither a business plan to guide 
workforce development nor a consistent model for substance-abuse rehabilitation services. There was no overarching vision for which types of houses to develop and how. And there were doubts about how Operation New Hope could consistently build quality housing if it were to train workers on the job rather than in advance.

Even as funders suggested ways for Operation New Hope to build its capacity, they recognized it as a uniquely powerful effort. By the start of 2002, the organization had restored and sold 17 houses and created about 40 jobs. Soon others were to learn of it as well.

\section{The Program Attracts \\ Greater national interest}

Operation New Hope was run by people of faith, and pastors did much of the informal counseling with program participants. But they did not proselytize, and the program's goals_housing and jobs-were more earthly than ethereal. On the surface, it might as well have been a secular organization. However, faith played an unseen but important role: as personal motivation for the people running the program. "The faith part of this program was in holding on," says Gay, "to keep doing the work."

Scouts from the US Department of Labor got word of the program. They found that Operation New Hope already had many of the components they were interested in: collaboration with the faith community and the criminal justice system, a viable program model, work with ex-prisoners and mentoring. In early 2002, Gay and Scott were invited to Washington to speak with the US Department of Labor, the US Department of Justice and the Congressional Black Caucus about their work in Jacksonville. It wasn't too long before they were selected as a national model for faith-based reentry programs.

In June 2002, spokespeople for the Department of Labor's Center for Faith-Based and Community Initiatives visited Jacksonville to announce that Operation New Hope would be the starting point for the Ready4Work initiative. Operation New Hope fit nicely with the Bush Administration's goal of boosting faith-based programming.

No funding had been allocated for Ready4Work at the time, but the prospect of federal support and the chance to serve as a national model buoyed the program staff. ${ }^{13}$ Funds came the next year, in 2003, when Gay and Scott were invited to meet with President Bush to discuss their work. 


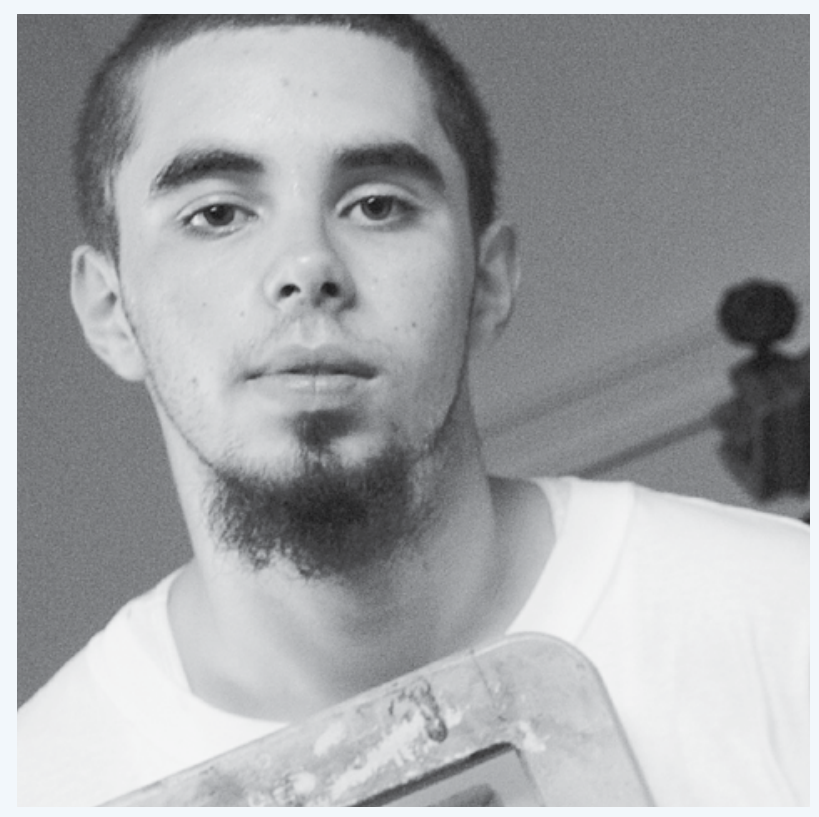




\title{
Memphis Case Study
}

\author{
HEARING THE CALL
}

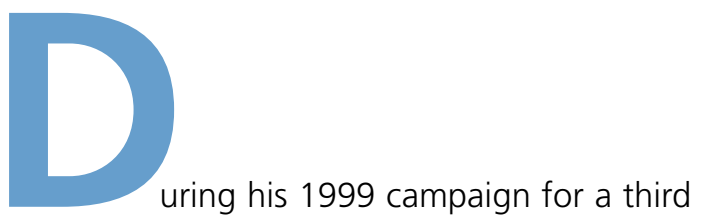

term as mayor of Memphis, Willie W. Herenton started hearing from ex-prisoners who were having trouble getting jobs. "The Lord was speaking to me through them," he declares. "They were saying, 'We're out here; we need help.'" Those who spoke with Herenton represented many more. Every year, upward of 2,000 people with felony convictions were released from prison into Shelby County, where Memphis is located. ${ }^{14}$ Their cries resonated with Herenton personally and inspired what would become a signature program of his administration, "Second Chance."

Born and raised by his mother and grandmother in racially segregated South Memphis, the young Herenton idolized black athletes-Joe Louis, Sugar Ray Robinson and Jackie Robinson-for their ability to survive in a tough world like the one where he lived. "In my neighborhood, virtually all the people who worked performed manual labor," he says. "There weren't any blacks there who had reached professional status." 15 Years later, after moving to Chicago to pursue a career in boxing, he was looking for a job. He saw a factory foreman angrily turn away a group of African American men seeking work. At a turning point, he decided he did not want to be subjected to the same treatment and returned to Memphis for higher education. There, he marched with Martin Luther King, Jr., for the rights of sanitation workers, shortly before King was killed. He taught elementary school, was appointed principal of the school he attended as a child and went on to earn his doctorate. In 1979 he was named superintendent of Memphis schools, and in 1991, he was elected mayor, the first African American to fill those positions.

So when ex-prisoners approached Herenton in 1999, he felt the tug of a lifelong personal conviction. "I believe as God forgives, that society ought to forgive," he says. Also, these were constituents like any other, and he was duty-bound as their mayor to serve them. 


\section{MAKING THE CASE}

Herenton used his considerable political skills to generate support for what he knew would be a tough sell-a city-funded job-placement program for ex-prisoners. The city council would have to approve a line item in the budget for the program, so the mayor would have to win the council's—and the public's—backing. He chose his first audience carefully, floating the idea in a wide-ranging policy speech at the meeting of a local Democratic organization in April 2000. Anticipating certain criticism, he said the program would not be for multiple offenders, and that it would take advantage of federal tax credits. Herenton also appealed to precedent, citing an existing federal government program that bonded businesses that hired ex-felons. ${ }^{16}$ The press and the public responded, both for and against. Supporters claimed that helping ex-felons find work would reduce recidivism and enhance community safety. Opponents complained that there were other more worthy programs on which to spend city time and money and that enough people without felony charges had difficulty finding work.

The mayor would have to justify the program to skeptics. He developed a position paper that featured President Clinton's executive order on assisting ex-felons, as well as letters of support from local leaders, judges, ex-prisoners and others who knew the value of such a program. Another letter of support came from Yalanda McFadgon, a former member of the mayor's security detail and herself an ex-felon, who wrote passionately about her difficulties in finding a job and her desire to work. The budget containing a line item for Second Chance was, after some opposition, passed, and the program moved forward.

In November 2000, the mayor assigned McFadgon to take primary responsibility for designing and implementing the program. He formally christened the new organization at a press conference in December. The local media doubted the value of the program and the ethics of hiring an ex-felon, especially one with close ties to the mayor, to serve as its head. Undaunted, the mayor launched Second Chance, with McFadgon as executive director, in January 2001.

\section{The Executive Director}

McFadgon had had experience on both sides of the law. A lifelong resident of Memphis, she served for 14 years on the city's police department, including as head of the mayor's executive security team. While in that position, she became involved in some illegal dealings to protect a family member and was sentenced to five months of incarceration and five months of home confinement. Once she finished her sentence, she began to look for a job. But whatever her achievements may have been, she was now marked as an ex-felon.

One humiliating job interview followed another, when she could even get that far in the application process, until she finally landed a position as the operations manager of an upholstery company. She felt taken advantage of there. Her employer knew she 


\section{Second Chance Program Design}

For the January 2001 launch, Yalanda McFadgon designed a program that, because of its strength and flexibility, remains much the same today. It covered nine steps:

1) Application process: Applicants must personally submit a completed application at the Second Chance office.

2) Background check: This ensures that eligibility requirements are met: applicants must be residents of Shelby County, must have only one felony conviction with any number of counts, can be of any age and are not restricted in terms of misdemeanor violations.

3) Profile analysis: A workforce development specialist interviews and creates a file on the applicant.

4) Panel interview: An exhaustive assessment of the candidate is performed by McFadgon and two other specialists.

5) Drug screening: Any participant who fails the drug screening is disqualified but may reapply a year later.

6) Orientation: A daylong orientation covers such topics as education and training, citizenship rights, conflict resolution on the job, mock interviews, soft skills and signing of the Second Chance Agreement. The mayor shakes the hand of each participant and makes a personal covenant with him or her.

7) Placement: Second Chance staff consult with employers about their needs and participants about their skills and try to make the best matches possible.

8) Follow-up case management: Workforce development specialists monitor the progress of each participant in his or her new job for one year. Participants have the option of taking additional job training.

9) Graduation: After 12 months of work, participants join family, friends, community leaders, program partners, staff and the mayor at a formal graduation ceremony in the Hall of Mayors at City Hall.

needed the job badly, and so he called on her to do more than other employees. In time, McFadgon found another job with a youth-services agency, whose director felt that her record should not rule her out.

It was synchronicity when the mayor told her of the many ex-prisoners who had been recounting similar obstacles in their job searches. McFadgon helped personalize the issue of reentry for the mayor, who told her, "I can't think of a better person to head this program than you." It was a big decision for McFadgon to accept this very public position, since the publicity relating to her conviction had been difficult to endure. A lifelong Baptist, McFadgon remembers coming to the conclusion that "if God chooses to use me like that, then I'll do the job." 


\title{
The Program Begins
}

\author{
"It was a bitterly cold day in Memphis," says McFadgon of January 2, 2001, \\ when Second Chance accepted its first round of applications. "We thought nobody \\ would apply."
}

Imagine her surprise, then, when a line of applicants wrapped around the downtown building where Second Chance had its humble office. In total, more than 1,000 people personally submitted applications that day. "We had no choice but to process them all," McFadgon says, citing the promise to receive all comers. However, only a relatively small percentage of the applicants qualified. Some did not meet the eligibility requirements, and others violated the "zero tolerance" policy that McFadgon maintained from day one. Anyone who did not fully complete the application form, did not deliver it him- or herself or arrived so much as a minute past the deadline was automatically disqualified. This policy emphasized the need for candidates to assume personal responsibility in the application process and, eventually, on the job.

Second Chance was a meager operation in the early months of 2001, consisting of McFadgon, a laptop, a telephone and a small room in the offices of the Workforce Investment Network, a two-story brick building just behind the central depot of the city's public-transit system. She had some temporary staff on loan from city government. More resources were soon to come, but McFadgon had to scramble to meet the demands placed on the program.

"I never wanted to set people up for failure," she says. When the second round of applications, the next month, again attracted more than 1,000 applicants, McFadgon realized she would have to limit her intake in some way. Otherwise, she would have more participants than she could eventually place in jobs. She decided from then on to accept only as many applicants, on a rolling basis, as she could place in jobs. And that meant finding more employers.

\section{BUILDING CAPACITY}

For the launch of the program, Mayor Herenton had secured promises of jobs for Second Chance participants from five employers: MS Carrier trucking company, the Memphis Housing Authority, Memphis Light Gas \& Water, the City of Memphis and the Memphis Area Transit Authority. With such an overwhelming number of applicants, it was now up to McFadgon to find additional companies that would accept program participants.

She took referrals from most any source, talked about the program at every opportunity and used her connections in city government and the local Workforce Investment Network to find prospects. She preferred face-to-face contact over phone calls because "It's easier for someone to tell you 'no' over the phone," she says. "So I always tried to get an appointment and make a presentation. For every time I've gone out to do a presentation, I've come back with at least one job." 


\section{A Concept Of Justice: Judge J.C. McLin}

Judge J.C. McLin—elected in 2000 to the Criminal Court—remembers seeing a lot of young men and women who had been convicted of nonviolent felonies and now could not find jobs. McLin was in a position to set the conditions of probation for the 300 to 400 people he oversaw at any given time and would order many to get a GED or a job. But in many cases, they had trouble finding jobs because of their felony record. "It got to be like a revolving door," he says. "The same people would end up back in the court system. And I had to ask myself why."

Second Chance, with its social and technical supports for ex-prisoners, made intuitive sense to McLin when it was proposed in 2000, and he "fell in love" with the program once it was rolled out in 2001. He started to assign as many people as possible to go to Second Chance. But the program could only take so many.

"The numbers are staggering," says McLin, of the number of people who go through the criminal courts. And when ex-felons are prevented from getting jobs, it puts a strain on the rest of the publicsupport system, he says. "A lady might lie to get food stamps to feed her kids, and if she gets convicted it's a felony. Then she can't get a job, and the system has to take care of her kids. We restrict people if we won't give them a job because they've had a felony, but then if they lie and get convicted-it's a catch-22 for a lot of people.

"The way things are now, we lock a person up to punish them, not to rehabilitate them," McLin explains. "We need more programs like Second Chance so we can give people a chance to get it right. That's what restorative justice is about."

Within two months, McFadgon was joined by four additional staff in an expanded office. The staff would later grow to include several workforce development specialists to case-manage the participants. From the beginning, McFadgon was the one primarily responsible for job development. While everyone on staff had job titles, she insisted that all employees be able to handle the various tasks outside their own position. "We don't get caught up in 'this is not in my job description' here. This is a team effort," she says.

The positions that McFadgon and her growing staff secured for program participants were hard won. Many employers had preconceptions about convicted felons, which she dispelled by revealing that she was an ex-felon and by telling stories about program participants. Other employers were reluctant to hire people with certain kinds of felony convictions, especially rape or murder. McFadgon emphasized that employers had access to candidates' case files and were free to rule out anyone convicted of certain felony crimes. She would also suggest that they consider mitigating circumstances on a case-by-case basis, such as an abused wife who killed her husband.

But McFadgon never asked employers to consider Second Chance candidates as a social service. This was also a good business proposition, she told them. By hiring program participants, employers were increasing the tax base; lowering crime and recidivism and thus raising the quality of life in the community where they operated; saving money on the exorbitant fees they would otherwise pay to a temp agency; gaining a 
dedicated employee who had been prescreened for drugs and given a thorough assessment and orientation and who would be case-managed for a full year. "We're not in the business of selling ex-felons," McFadgon says. "We're in the business of selling good employees."

With the attitude that her "customers" were the employers, McFadgon reached out to local companies. After some tough going at first, she secured agreements with 10 to 15 new employers a year until the introduction of Ready4Work in the fall of 2003. She constantly sought to diversify the pool of employers, explaining, "For the sake of the program's security, I would rather have 100 companies that each hired one person than one company that hired 100 people." Relationships with employers had to be massaged regularly. If an employer's primary liaison, such as the human resources director, left the company, Second Chance would be sure to establish relations with the replacement person.

"The stronger your workforce, the more businesses you can attract to your city," says Isaac Garrett, the executive director of the Memphis Workforce Investment Network (WIN). From the start, WIN partnered with Second Chance, offering its core services (orientation, job screening, etc.) and, pending eligibility, vocational training to ex-prisoners in the program. WIN's mission, to connect people with jobs, required that the agency serve employers and employees alike. Ex-prisoners constituted another source for the labor pool, and, once trained and placed in jobs, they could help boost the city's economy. "You want to try to train workers in areas where there are jobs," Garrett explains, citing product distribution, warehousing, health sciences and hospitality as being among the strongest sectors in the Memphis labor market. "They get jobs, and employers get the skilled workers they need."

\section{WORKING WITH PARTICIPANTS}

"I've been called every name you can imagine," says McFadgon, of her zero-tolerance policy for program violations. People who were disqualified from the program for what they considered minor infractions - five minutes late to an interview or having a friend drop off the application-were often left upset and angry. But since the relationships with employers were so hard won, any failings on the part of a Second Chance participant could reflect badly on the program and require damage control from McFadgon. "We have always had to be very strict," she explains, "in order to create a good product. Because we're selling a product-ex-felons—that nobody wants." Such austerity earned Second Chance a reputation for sending out good job candidates, and employers would in turn open up more jobs for ex-prisoners.

With a strong stream of applicants, program staff did not have to recruit participants for Second Chance from the prisons or anywhere else. Even so, the staff sought to develop relationships with people in all areas of criminal justice-probation and parole officers, judges, law-enforcement officials, corrections officials - to demonstrate their shared commitment to reducing crime and recidivism. 
"People are hungry, and they want to participate," says McFadgon. In many cases, the application process was the first time when candidates felt they could be open about their criminal record with someone in a position to help them get a job. It was not uncommon for candidates to cry with relief during the panel interview.

Other displays of emotion lay in store for the roughly 25 percent to 40 percent of participants who reached the orientation stage. Following the orientation, participants would swell with pride when they met with Mayor Herenton. "I shake hands with each person," he explains. "We have a bond that when they are assigned a job they are going to work to be the best employee for that organization."

Then the real work would begin. Workforce development specialists would try to connect participants with jobs aligned with their skills and interests. Participants were not required to accept job offers; some would go on multiple interviews before taking a position. Workforce development specialists would then conduct follow-up case management on a monthly basis, or more often as necessary, for the first year of employment. The zero-tolerance policy remained in effect throughout the course of that year, and participants who violated the terms of the agreement they signed during the orientation were disqualified and not allowed to reapply.

The first application process through the first job placements took about three months. During the following year, at the end of which the participants would have their first graduation, McFadgon and her staff continued to develop relationships with employers, people in corrections and program participants.

\section{BUILDING BONDS}

"In the early days, I had a lot of one-on-one with participants," McFadgon recalls fondly. "I miss it. They didn't necessarily want guidance. In many cases they just wanted someone to listen. They'd come in and talk about their girlfriends, or their family or later, about their new job."

Though the program had no formal mentoring component, these sorts of encounters-simple human contact—built the bond between Second Chance staff and participants. McFadgon herself selected staff. "To work in this field," she says, "you have to have good people skills. And you have to have a certain amount of realness for participants to trust you." Several staff members were themselves ex-prisoners and could more readily identify with participants' struggles. In time, several program graduates joined the staff.

The graduation ceremony that caps participants' formal involvement in the program is a moving event. The first graduation, as with successive ceremonies, was a milestone in the program's development. Twenty-six participants graduated in early 2002 after a year of successful employment. 
In the roughly twice-annual ceremonies, at the beautiful Hall of Mayors in Memphis City Hall, family, friends, community leaders, program partners, staff, the mayor and others watch as program graduates give testimonies about their experience and receive certificates of achievement.

Following the ceremony, there is a festive reception, with cake, a congratulatory banner and a photographer who takes pictures of each graduate with the mayor. As the city's Chief Administrative Officer Keith McGee puts it, "They have joined the mayor's vision. It's very rewarding to see." McFadgon adds, "There are grown men crying, feeling whole again or feeling like a man again. The mayor has cried. Everyone has cried at these ceremonies!"

"These are folks who had given up hope. They say they've tried everything but just can't find a job," she continues. "And it's exciting that they can find a job with us, and now they can buy Christmas gifts for their kids or buy a class ring. It's very satisfying for me to see how you've made a difference in someone's life. It keeps me going." One can't help but think that that bond has helped keep the program going as well. "Once you go through the Second Chance program," McFadgon says, "you become part of the Second Chance family."

In 2003, Second Chance received funding to implement Ready4Work; it now operates as "Second Chance/Ready4Work," with different eligibility criteria for the two programs. 


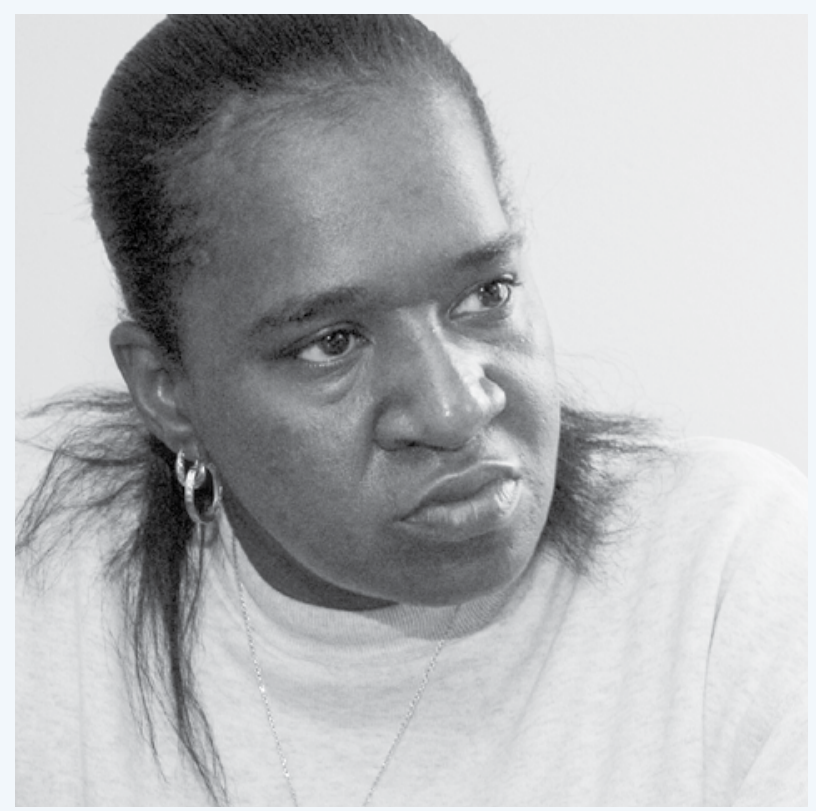




\title{
WASHINGTON CASE StUdy
}

\author{
The Most Positive Thing
}

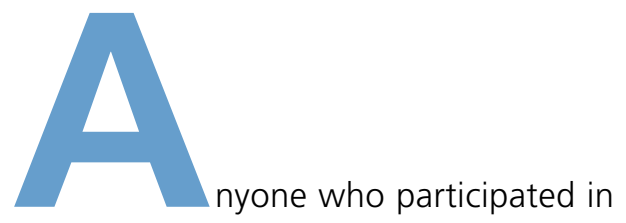

Washington DC's first "Reentry Sunday" in January 2002 could be forgiven for thinking that things had always been this good. The event focused attention on the faith community's role in reentry work. A press conference the week before featured Mayor Anthony Williams, Rep. Eleanor Holmes Norton and other dignitaries and drew substantial media attention. On Reentry Sunday itself, politicians, reentry experts, and clergy spoke at dozens of churches, mosques and synagogues around the city about how the faithful might help some of the 2,500 ex-prisoners returning to the city every year to reintegrate. ${ }^{17}$

"Too often, we forget these individuals are part of our community, and they come back," said Mayor Anthony A. Williams. "We must mentor our returning inmates just like Moses mentored Joshua." 18

The nation's capital had its top politicians urging people of faith to help ex-prisoners become productive citizens-for the benefit of the ex-prisoners themselves and the communities they returned to. And the whole affair was orchestrated by a fully funded government agency, the Court Services and Offender Supervision Agency (CSOSA), created in 1997 to supervise the more than 10,000 people on parole, probation and pretrial release in the District of Columbia. ${ }^{19}$

Rev. Michael Bryant, the DC jail chaplain for 22 years, called the Reentry Sunday program "the most positive thing" he had seen happen in the local court system. 20 Years of conversations and planning had gone into this and other related programs. Two agencies-CSOSA and a grassroots community organization called East of the River Clergy-Police-Community Partnership (ERCPCP)—had each been organizing the faith community around reentry. Both organizations keenly understood what was at stake. CSOSA, with its large caseload, was well aware of the magnitude of the reentry crisis. And ERCPCP saw the painful effects of the crisis on its East of the River neighborhood every day. Then, as now, "youth in the revolving door of the criminal justice system is one of the number one factors influencing public safety in our community," says the organization's executive director, Rev. Donald Isaac. He saw firsthand the faces behind the statistics: On any given day, nearly one in three young African 
American men was in prison or jail, on probation or parole. ${ }^{21}$ For CSOSA and ERCPCP, reentry was no distant issue but rather an urgent and difficult problem. Their separate efforts to address it would converge in a unique and powerful way.

\section{CSOSA'S PATH}

Before CSOSA was created, people incarcerated in the District's prison system returned to the community with minimal transitional support and supervision. "At that time, it wasn't unusual for caseloads to exceed 150 people per parole officer," says CSOSA Associate Director Cedric Hendricks. "I think you can imagine how much attention and support each parolee would get."

"Most DC parolees lacked the basic skills to successfully negotiate their environment, were unemployed or unemployable, lacked basic literacy skills and had substance-abuse problems," says a study CSOSA conducted before initiating the new reentry system. ${ }^{22} \mathrm{~A}$ high number of parolees with so many needs and so little support was a recipe for recidivism.

A gathering mass of political will led to the formation of CSOSA in 1997, its mission "to increase public safety, prevent crime, reduce recidivism and support the fair administration of justice in close collaboration with the community." 23

It was perhaps only a matter of time before faith institutions joined the constellation of community organizations working with CSOSA. The idea had had a long gestation period. Former DC Director of Corrections Walter Ridley recalls having had conversations as early as 1987 about the role the faith community might have in reentry. Agency Director Paul Quander, Jr., later explained, "Effective community supervision is not just the prevention of wrongdoing, it is the encouragement of right-doing. That is why in 2001 we reached out to the city's clergy and began our Faith Community Partnership." 24

It started simply enough. In the summer of 2001, the agency sent out letters and made follow-up calls to hundreds of clergy citywide, inviting them to a meeting to discuss how their houses of worship might work in collaboration with CSOSA. Contacting clergy was not always easy, explains Hendricks. "You've got some churches that are only open on Sundays and some that are open throughout the week with full-time staff. Some don't have a regular phone line."

Organizers were pleased when about 40 clergy attended the July 2001 meeting. Some pastors said CSOSA's mission resonated with their own. Still, others who didn't attend may have been wary. The Rev. Herbert C. Bruce, of Pilgrim Baptist Church in Northeast Washington, says that although people were enthusiastic early on about helping, they were also unsure of how it would all turn out. "I think if you have a church saying they didn't go into this with trepidation, they're lying," Bruce says. "We didn't know what to expect." 25 
Attendees laid the groundwork for what would become a series of meetings throughout the fall and winter of that year. They drew in other clergy to become a part of the working group, which was called the CSOSA Faith Advisory Council. The Council was chaired by Rev. Donald Isaac, the recently named director of ERCPCP.

The Faith Advisory Council agreed to sponsor Reentry Sunday in January 2002. Timed to coincide with Martin Luther King Jr.'s birthday and with the National Mentoring Month declared by President Bush, the event urged parishioners in congregations around the city to help ex-prisoners reintegrate back into society. With press coverage, official interest and some 40 participating congregations learning about reentry, the event was an unqualified success.

Capitalizing on the interest aroused by Reentry Sunday, the Faith Advisory Council called another meeting in February, and more than 300 people showed up. Careful not to let the flame of excitement die out, organizers collected complete information from attendees on their various ministries, organizations and how to contact them. CSOSA encouraged volunteers to continue to participate but also plainly stated the demanding nature of reentry work. "Some churches that came out at the onset didn't stay," says Hendricks. "We were so into pushing forward, we didn't spend a lot of time chasing down those that opted out. There are a lot of ways to help people." CSOSA focused its energies on retaining those who, having been properly oriented to reentry work, chose this way.

A volunteer faith-based mentoring program for ex-prisoners was emerging as a key element of member institutions' work. CSOSA staff and the Faith Advisory Council designed a training program for volunteer mentors; it had components on community supervision, CSOSA and the dynamics of working with returning offenders. The first nine-hour training was held in April 2002 at Pilgrim Baptist Church. Mentors were recruited from faith institutions, and mentees were recruited from halfway houses or "community corrections centers." The first matches between mentors and mentees were announced three months later, in July.

CSOSA's Faith Advisory Council had captured the interest of hundreds of clergy. The trick now was to harness this energy and create a sustainable program. CSOSA created a structure that divided the city into three service areas or "clusters," each of which would have a lead agency. Following a competitive application process, lead agencies were selected in May 2002, and a contractual relationship was established with each. 26 CSOSA would provide funding, direction and technical support and required that participating faith institutions have at least three trained mentors. The lead agencies would hire a "cluster coordinator" to organize faith institutions in their cluster to recruit and manage the mentors and provide referrals and other services to ex-prisoners. Together, CSOSA and the lead agencies in each cluster would refine training and assess mentees and mentors to make the best matches.

The ERCPCP was selected as the lead agency for Cluster A. The organization had demonstrated its organizational capacity, financial soundness and commitment to CSOSA's goals. In fact, ERCPCP had followed a parallel path working with ex-prisoners. 


\section{ERCPCP'S PATH}

In 1999, a spike in homicides in DC's East of the River area raised the concern of Chief of Police Charles Ramsey, who had been appointed the year before. Ramsey had brought with him a conviction that the police needed the cooperation of the communities they were sworn to protect. He heard of a Rev. Anthony Motley, a DC native who, after serving a prison term in the 1970s, had gone on to form Inner Thoughts, a summer enrichment program for youth, and still later, Redemption Ministry, an outreach ministry aimed at addressing violence and substance abuse among young people. Ramsey directed an assistant chief to meet with Motley to discuss how the police and clergy might team up to reduce violent crime in the area. They resolved to enlist the support of other local clergy.

With the support and resources of the Metropolitan Police Department, the two men invited some 250 East of the River religious leaders to a meeting to discuss youth crime. Twenty pastors attended, which they considered an excellent first turnout. Rev. Motley and Chief Ramsey spoke and presented a video on Boston's renowned "Ten Point Coalition" to reduce youth crime. The assembled ministers adapted the model and produced what they would later dub their "Seven Point Plan" to guide youth and community development activities. They called themselves the East of the River ClergyPolice Partnership. Because of the ensuing involvement of other organizations, the word "Community" was later added to the name.

News of the group had spread by word of mouth, church bulletins, sermons and other gatherings. "We were persistent," says Motley. "A lot of people ask churches for something and don't give anything back. We didn't try to force anything on anybody; we would just show clergy the Seven Point Plan and ask them where they might fit in."

\section{ERCPCP'S Seven-Point Plan}

The East of the River Clergy-Police-Community Partnership (at the time without the word "Community" in the name) adapted the model of Boston's renowned Ten Point Coalition to its own needs. Participating clergy each dedicated their efforts to one of the seven points, designed to reduce violent youth crime in the city.

1. Connecting services to youth and families

2. Removing the fear factor

3. Collaborating with the criminal justice system

4. Strengthening the value system of the youth

5. Providing youth spiritual development

6. Offering grief and counseling support

7. Fostering stabilization, independence and productivity 
Successive meetings of the Partnership attracted 20, 30 and-by the fall of 1999some 40 people. At a daylong planning session that several at-risk youth also attended, the group decided to enlist community social service providers. Funding for the burgeoning partnership came from various institutional donors.

Motley created a more formal infrastructure to guide the organization's growth. He secured funding and technical assistance and guided the group in establishing objectives, activities, outcomes and methods of assessment for each of the seven points. A December 1999 press conference launched the effort, and its first major event, "Truce 2000," called for an end to shootings and successfully brought together area gang leaders to work out their differences peacefully. The event received major press coverage and attracted the attention of P/PV, which, acting as an intermediary for the Ford Foundation, later funded the effort to stem youth violence. Motley was acting as the volunteer executive director, but the Ford Foundation recommended that the director not be a pastor so s/he could work full-time for the new Partnership. In April 2000, Rev. Donald Isaac, an assistant pastor at a local church and the former auditor and later chief financial officer of the Council of the District of Columbia, was selected as the new executive director. For the first few months, he was the only staff member and worked at home.

Within just one year, the group had grown from a small handful of participating clergy to an established 501(c)(3) with a board of directors, 25 active member churches, 20 community organizations, five law enforcement entities and partnerships with several national organizations. The group continued to offer an increasingly large set of services and events, such as gang interventions, youth peer-counseling sessions, festivals and concerts, retreats, prayer vigils and forums. It also sponsored a small grants initiative to fund area churches' efforts to further one of the seven points. As funding had grown, so too had the staff, to 10 members by late 2001, who worked in an office building in the heart of the neighborhood. Youth-violence-prevention activities continued apace, and by the summer of 2001, circumstances led the organization to direct its attention to ex-prisoners.

\section{ERCPCP BEGINS TO WORK WITH EX-PRISONERS}

ERCPCP and CSOSA were acting on parallel tracks-pairing clergy and the justice system to reduce crime and recidivism - but not in any formal collaboration. CSOSA, in July 2001, called its first meeting of the Faith Advisory Council. CSOSA had asked Rev. Motley to chair the council, but, citing other responsibilities, he recommended Rev. Isaac, who agreed.

Meanwhile, in his capacity as leader of Inner Thoughts, Rev. Motley had trained some ex-prisoners to serve as mentors to at-risk youth in the neighborhood. ERCPCP had also built relationships within the criminal justice system and in the faith community. The organization recruited volunteers for a burgeoning prison ministry and ex-prisoner mentoring program. By the time CSOSA put out a request for proposals for lead 
agencies in its Faith Community Partnership, ERCPCP was primed to fulfill that role for Cluster A, in the southeast section of the city, and was selected to do so in May 2002. The organization would now be funded to train mentors for returning ex-prisoners.

\section{WORKING WITH MENTORS}

Now with more staff, ERCPCP was better equipped to formally recruit mentors to help ease ex-prisoners' transition back into the community. The organization's "cluster coordinator" took primary responsibility for this task. That person worked with five congregations and another faith-based organization: Upper Room Baptist Church, Paramount Baptist Church, Higher Ground CME Church, Grace Apostolic Church, Faith Presbyterian Church and the Anacostia Men's Employment Network (AMEN).

A pool of 150 trained volunteers interested in prison ministry and reentry formed the basis for their efforts. The cluster coordinator, in cooperation with other Partnership staff, continually worked to recruit additional houses of worship to participate. But as Isaac explains it, "Just because your church, mosque or synagogue realizes the faith mandate to work with this population, not everybody is suited to this work. Some might do better writing letters or working with the children of prisoners."

For those who were suited to the work, CSOSA's nine-hour trainings equipped them with the knowledge and skills necessary to become mentors. Early on in the trainings, says CSOSA's Cedric Hendricks, "We tended to overwhelm people with information about agency operations, but we cut back on that. We added more material about how to break the ice with ex-prisoners and about the importance of talking and listening," as opposed to lecturing or preaching. Mentors were trained to learn about mentees' lives, experiences and goals and how they could best serve them. In time, CSOSA found it increasingly important to document these contacts. Reporting on the relationship helped mentors reflect on and improve their own performance, and it helped CSOSA effectively monitor the program as the number of referrals increased.

ERCPCP calls its mentors "life coaches." Rev. Isaac notes that much of the literature on mentoring comes from Big Brothers/Big Sisters and is not applicable to working with adult ex-prisoners. Participants felt they didn't need a "mentor" as such and that the very term belittled them. With the input of the ex-prisoners, ERCPCP arrived at the more descriptive term "life coach."

"This population isn't going to run to you with open arms," says ERCPCP's reentry director Julia Irving. In order to successfully recruit and retain participants, she says, a program needs good mentors. "We've learned that you definitely want to partner with an organization that has a strong men's ministry, and you need the buy-in of the pastor," she says.

At first, ERCPCP paid faith institutions that recruited life coaches to cover costs they incurred and to appropriately value the time and energy required to recruit and manage the coaches. Money complicated matters in two ways, however. It called into question the validity of the information that participating faith institutions gave to ERCPCP, such 
as number of mentors or hours served. In addition, some churches came to expect the funding. So when that pool of money dried up, some of the faith institutions stopped participating. ERCPCP had to recruit more aggressively and state clearly that the Partnership could not provide any funding. Participating churches had to be motivated strictly by a desire to serve.

"I'm pulled to those who are less fortunate," says Rev. Lula Bell, a life coach and an associate pastor at Paramount Baptist Church. "I came from a family of poverty, but the Lord has been good to me. I've been blessed, but I haven't forgotten where I came from." Though on staff at Paramount just since 2001, she has been a parishioner for more than 30 years. In 1972 she started a day-care center and also began to work with "those who seemed to have fallen." Many of them, as it happened, were ex-prisoners.

Once Paramount linked up with ERCPCP to do more formal mentoring, Bell went through the training program for mentors, even though she had already had plenty of informal experience. The training covered how to approach ex-prisoners, avoiding getting into sticky situations, personal safety, providing referrals and dealing with ex-prisoners' families. ERCPCP provided ongoing practical and emotional support.

Participants presented such problems as substance abuse, HIV and other health issues, trouble finding housing and a tendency to slip into their old ways. Bell says, "You're not just focusing narrowly on the job situation. It's about working with the whole person."

\section{WORKING WITH PARTICIPANTS}

If it was faith that led mentors like Rev. Bell to work with "the whole person," it was also faith that led some ex-prisoners like Kenny Glover to allow themselves to be helped. In the fall of 2002 Glover was back in southeast Washington after a six-year prison sentence and a stint in a halfway house. "By the grace of God, I landed here at ERCPCP. Rev. Isaac didn't have a job for me then, but I would leave the halfway house and rake leaves or do odd jobs. I told him that God told me to be here." By Glover's account, Rev. Isaac prayed on it and helped him get a job with a small remodeling business as a test of his commitment. He was later hired as an intake specialist at ERCPCP.

"When I was doing the intakes on these guys" —ex-prisoners like himself_-"I was actually working on myself. By helping them, I was helping me, too," he says.

Glover had grown up on the other side of southeast DC from ERCPCP's offices. "It was a typical thing, going to school, getting in trouble, smoked my first joint at age 11 -and my childhood was gone. From that point on I was off to the races-arrested 70 times and incarcerated maybe 20 times up until I was 28. I broke into 15 stores in downtown DC and broke into a hotdog stand right by the FBI building —-that's how down I was!" At 28 he started serving a six-year prison term and also resolved to become clean and sober. At age 34 he was released and calls his time since then "the most productive of my life." 
By the time he was hired as an intake specialist at ERCPCP, Glover was well enough along in his own recovery and reintegration to be able to help. Soon after release from prison, Rev. Isaac says, many people are eager to contribute to the program. "What we found is that you have to be very cautious and intentional in how you allow a person to 'give back.'" As a rule of thumb, Isaac says that a person should be out of prison, clean and sober for 18 to 24 months before being allowed on staff. That time allows a person to acclimate to the city where he or she lives, stabilize in their sobriety, integrate the life and job skills they are taught and hence be better equipped to help other ex-prisoners. And even then, not every program participant is fit to work for the program itself.

Aside from walk-ins like Glover, participants are usually referred to ERCPCP by CSOSA or another community agency, such as Rev. Motley's Inner Thoughts or Redemption Ministry. Previously, ERCPCP had worked with youth ages 14 to 24, then expanded it to include youth age 12 to 26 and finally, as CSOSA's lead agency for Cluster A, removed the age limits altogether. ${ }^{27}$ In practice, however, the bulk of clients were still young people.

Case managers on ERCPCP's staff would stay in regular contact with program participants and assign them life coaches where possible. Case managers also helped participants to find housing, manage their finances, navigate the system for such essentials as driver's licenses or food stamps and, of course, secure employment.

ERCPCP referred Kenny Glover to Miller \& Long Concrete Construction, where he was hired. With the support of ERCPCP, "I was persistent and came to work on time," Glover says. "They sent me to school and paid for it. They wanted me to succeed."

"For years I just wanted my mom to say she was proud of me, but I had never given her something to be proud of. When I came home she told me she was proud of me. That was one of the biggest days of my life, and I knew that I had changed my life around."

\section{WORKING WITH EMPLOYERS}

Miller \& Long Concrete Construction was among the first employers to take workers referred by ERCPCP. Miller \& Long and other companies were part of the network of employers that Rev. Motley had developed through Inner Thoughts and another organization he had formed in 2001, the Jobs Partnership. He shared those relationships, creating the foundation for a growing number of employers affiliated with ERCPCP. Other employers included union companies, factories, warehouses and major chains like Safeway and Home Depot.

Job developers on staff were responsible for recruiting additional employers willing to hire ex-prisoners through the program and communicating with those employers about particular job candidates.

"Early on, we had some major employers at the table," remembers Rev. Isaac. "We made a high number of referrals, but we had a low level of retention. At the request of 
employers, we went back to the drawing board to see how we could present a more job-ready worker." The organization hired job readiness trainers to prepare candidates for job interviews, workplace etiquette, conflict resolution and communication. They also beefed up the mentoring or "coaching" component of the program. The result was a higher retention rate, more satisfied employers and a greater ability to recruit and retain other employers.

The way Jesus Hidalgo earns the trust of ex-prisoners who come to work at Miller \& Long Concrete Construction, where he is the human resources director, is to tell them a bit about himself. "I tell them I'm an immigrant, started working here as a laborer and that I had goals and dreams and really wanted to do something with my life. I wanted a career," he explains. "For them to see that I was talking from my life experience, about the things I'd overcome, it made them realize that they can do it, too."

Miller \& Long started hiring ex-prisoners from ERCPCP in early 2003. "We'd been operating since 1947 and figured this was a good way to give back to the community," says Hidalgo. The company's owner had started to build relationships with various faith leaders two years before, including Rev. Motley, who made a personal appeal for the company to hire ex-prisoners. At first it was just a few people. Some stayed on only until they got a paycheck or two; they had some money and wanted to return to their old lives. But as ERCPCP started to provide more intensive wraparound services, the employees became more reliable and stayed on longer.

Hidalgo says he learns something new every day from ex-prisoners, perhaps most importantly that "it's never too late to turn your life around." He cites as an example Kenny Glover, who started work with the company in his mid-30s. As Hidalgo recalls, "One of his first days on the job, he exclaimed, 'What an opportunity, to have someone who believes in me!'"

But it's not just the good feeling that inspired Miller \& Long to hire ex-prisoners. Hidalgo says it also helps the local economy to hire local workers, who will spend their money right in the District. "It's just good business to hire ex-prisoners. The business we're in, we need people."

\section{MAINTAINING BALANCE}

As the program grew, Rev. Isaac found himself having to strike a balance between two aspects of the program. His organization was part of a growing national movement to reintegrate ex-prisoners back into the communities they came from. The grassroots temperament of a movement was sometimes at odds with the more formal temperament of a nonprofit program, as required by funders.

"Programs have a start date and an end date. A movement is ongoing," says Rev. Isaac. "Programs have an isolated view of what they're doing. In a movement, you're connected to people you don't necessarily know. Programs generally look at the funding source as the ultimate authority, whereas a movement looks at the Supreme 
Being as what will bring ultimate success. There is built-in tension between those two paradigms. Along with compassion, there must be competence. We don't compromise our mission, but we remain responsible to the funders."

With substantial experience in navigating the worlds of faith and public policy, Isaac was well equipped to add to the conversation behind Ready4Work. And Ready4Work's founders were likewise eager to bring the best of both worlds-grassroots faith-based work with formal nonprofit capacity-building — to bear on the problem of bringing exprisoners home.

ERCPCP became a member of Ready4Work in October 2003. 


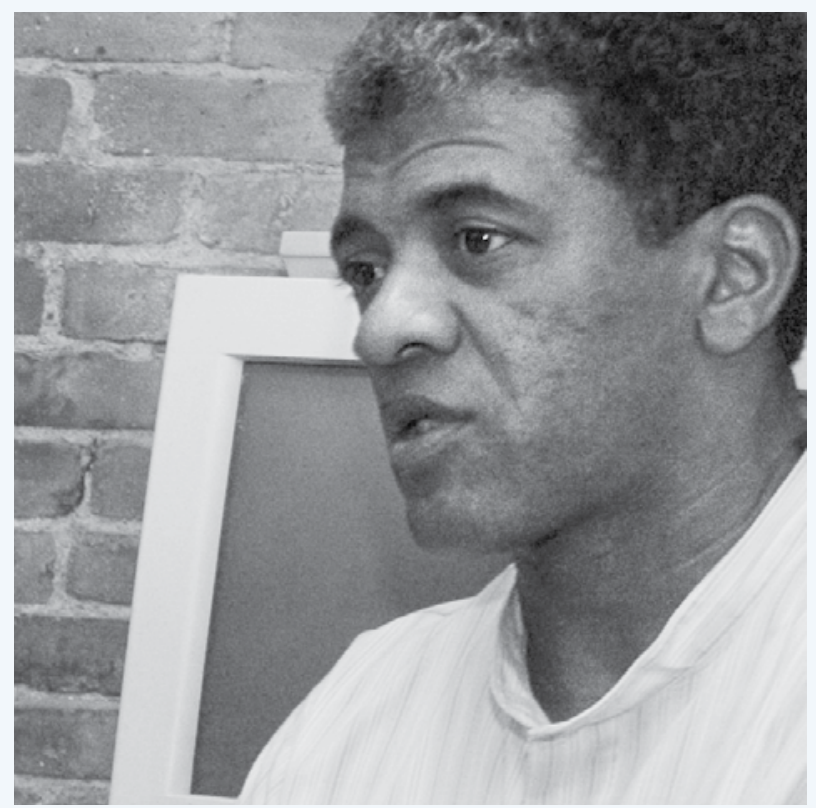




\title{
CONCLUSION
}

\author{
PioneERS IN REENTRY
}

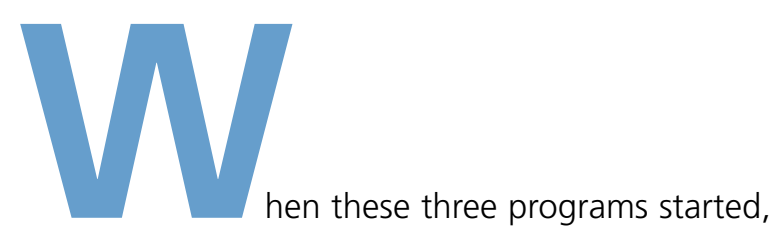

they were responding to needs they saw in their local communities, and without the benefit of a national initiative to guide their efforts. There were no established best practices, no national conferences on working with ex-prisoners, no steady funding streams and no Ready4Work. They were, in a word, pioneers.

Each program was the product of the people who made it and the circumstances and communities in which they were working.

In Jacksonville, Kevin Gay put his experience in the homebuilding industry to use by restoring homes for low-income residents. Then his Operation New Hope started to integrate itself still more into the community by hiring local people in need of a job to do the work. Rev. Garland Scott and other clergy provided an ongoing source of support, to keep workers hooked into counseling, recovery and training services. In time, the organization would benefit, and benefit from, a broader community interest in reentry sparked by the Jacksonville Community Council report. Business, faith and other civic organizations would all make this homegrown effort a success.

From one point of view, the Second Chance program in Memphis could not be more different than Operation New Hope. Conceived and supported by the mayor, Second Chance would seem to take a top-down approach, rather than the bottom-up approach seen in Jacksonville. But in its own way, Memphis responded to local needs as well. Ex-prisoners approached the mayor in the first place, inspiring his efforts, and the program was designed and administered by Yalanda McFadgon, an ex-prisoner who went on to create the "Second Chance family." The program structure she created was strong and flexible and would help the organization accommodate more participants and more employers than originally anticipated.

In Washington, DC, parallel efforts being made by community organizations and government entities eventually converged, creating a unique response to the local reentry problem. CSOSA sought the participation of local faith-based organizations. Meanwhile, ERCPCP had been working with youth in the criminal justice system, and 
so it needed stronger ties with police and corrections. When CSOSA asked for proposals from agencies to collaborate on reentry, ERCPCP was ideally positioned to serve in that role.

A businessman's homegrown effort that develops structure and staff-and a focus on ex-prisoners-over time. A mayor's program to put ex-prisoners to work to reduce crime and recidivism. A local faith-based nonprofit and a city government agency working together to further the same ends. These initiatives made way for Ready4Work, and the lessons they learned in their early days of programming are still valuable today, even in light of the strong infrastructure that has since been built.

Their experience shows that internal components (including model, structure, services, staffing and leadership) and external relations (with local government, the criminal justice system, community organizations, churches and employers) are key to creating a successful reentry program:

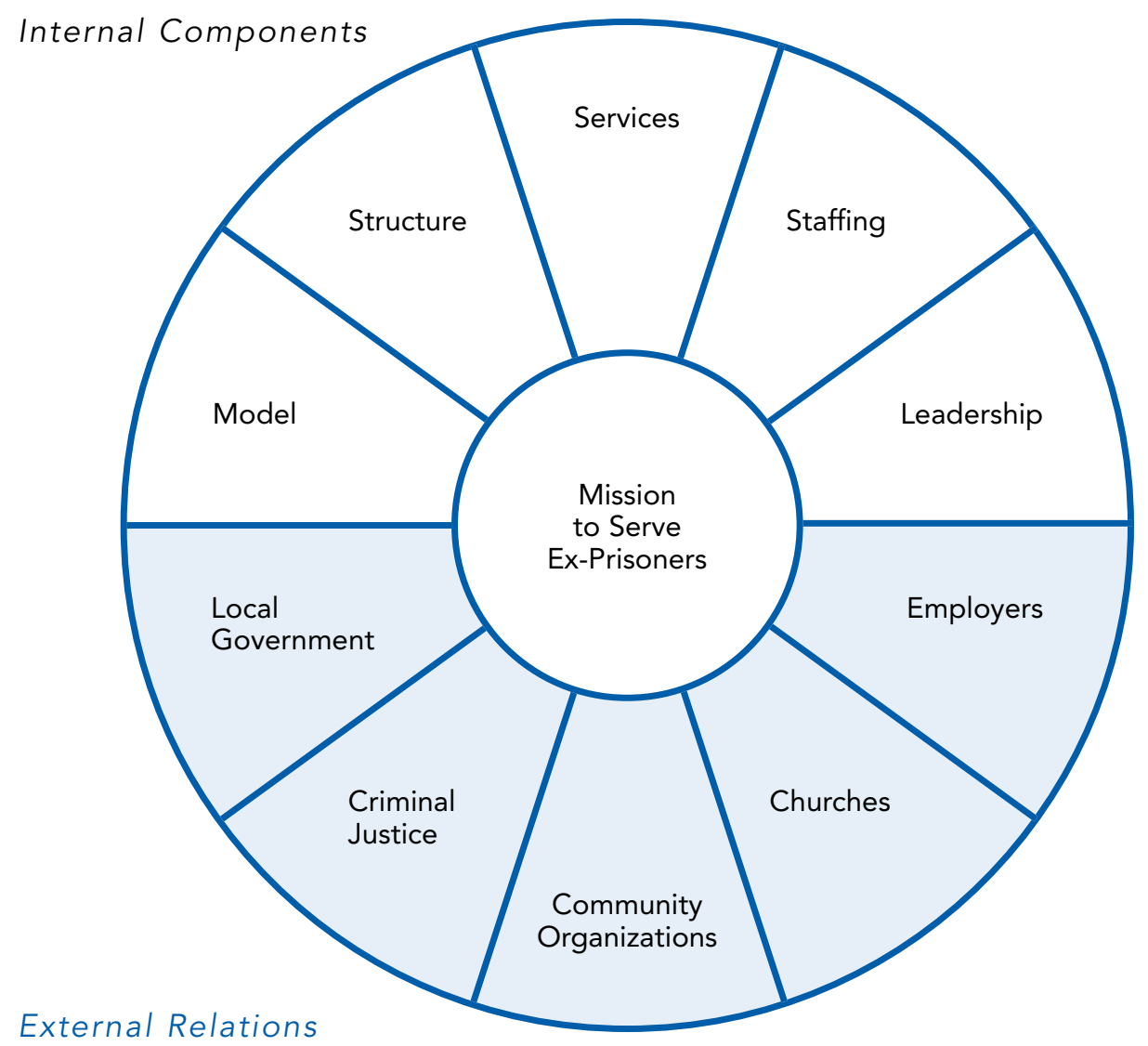




\section{INTERNAL COMPONENTS}

The workings of an organization-its model, structure, services, staffing and leadership-are the nuts and bolts that make it go. The experiences of the organizations profiled here suggest lessons for how other programs might structure their work to help ex-prisoners succeed in their transition.

\section{MODEL}

A successful program model must address the needs identified in the organization's mission and draw on the resources available in and outside the organization to meet those needs. The needs an organization identifies may be those of ex-prisoners, employers, the community at large or others. For example, Operation New Hope realized that, even when they had a job, many clients were falling through the cracks; once the program teamed up with a substance-abuse-recovery organization and started informal mentoring, participants were more able to stay on track with work. In this way, Operation New Hope adapted its program model over time, as experience dictated. A successful model should also balance program capacity with program demand. Staff in all three cities spoke of a similar frustration: The problem is so great, but they are so relatively small. FOR ALL THEIR SUCCESSES, THESE PROGRAMS ARE SERVING ONLY A FRACTION OF THE NUMBER OF EX-PRISONERS REENTERING THEIR COMMUNITIES EVERY YEAR: However well intentioned they may be, organizations that try to serve too many people risk spreading their resources too thin. This may set clients up for failure, as Yalanda McFadgon puts it, by not providing enough wraparound services and support. By creating a sustainable program model—such as the way Second Chance accepts only as many participants as it can place in jobs-an organization boosts its chances for ongoing success. In order to create this balance, reentry programs should assess both the demand for their services, such as through surveys and discussions with partners in the criminal justice system, and their ability to meet that demand, especially in terms of resources available.

\section{STRUCTURE}

A similar evaluation process is needed in order to create a strong, flexible organizational structure. A successful structure must plainly outline roles and responsibilities, and facilitate the flow of information among staff, board and other personnel. In Washington, a clear system guides CSOSA's work with community-based organizations. The lead agency for each geographical cluster has a liaison to relate with CSOSA. The lead agency contracts with local churches to recruit mentors, and a mentor coordinator manages these relationships. At ERCPCP, a workforce development specialist recruits employers who are willing to hire ex-prisoners. At every level, staff communicate with one another in regularly scheduled meetings and through program documentation. This structure helped them manage a large number of volunteer mentors and answer the reporting needs of CSOSA, a government agency. In Memphis, the Second Chance program was structured to meet different needs. While each staff person has a title and a role, executive director Yalanda McFadgon says that all staff are trained and expected to handle job functions outside their specific purview. For example, an intake specialist should be equipped to speak with a prospective employer. This more flexible structure 
worked well for Second Chance, whose staff members all worked in the same office and so had easy access to one another. In both cases, these structures ensure that all of the organization's functions are fulfilled and that information about program needs are understood by all involved. In order to design such a structure, an organization must assess what roles and responsibilities must be fulfilled, what personnel are available to perform them and how to achieve them with maximum communication and minimum redundancy. WHATEVER THE STRUCTURE, IT MUST BE WELL DEFINED AND COMMUNICATED WITHIN THE ORGANIZATION.

\section{SERVICES}

As all these programs have discovered, ex-prisoners must have various other needs fulfilled-such as transportation, health care, substance-abuse treatment and education-in order to get and keep a job. Fully-funded reentry programs may be able to provide the necessary services in-house. More fledgling organizations might partner with substance-abuse-recovery groups, soft-skills training organizations, or public-transit fare-discount programs to make sure workers are indeed ready for WOrk. MENTORING -INFORMAL AND FORMAL-SEEMS TO HELP PARTICIPANTS STAY ON TRACK FOR SUCCESS and provides them with an important social outlet, especially critical for those whose family ties were broken while they were in prison. Ex-prisoners also need career-enhancement opportunities, such as vocational-training classes, job networking or brushup courses in the latest computer programs. VoCATIONAL TRAINING SHOULD BE TARGETED IN AREAS WHERE LIVING-WAGE JOBS ARE PROJECTED TO BE AVAILABLE. For example, Second Chance partners with the Workforce Investment Network to assess the job market; Operation New Hope works in an area that sorely needs quality, affordable housing; and ERCPCP stays in contact with its network of employers to see which jobs are available and in demand. In all these cases, reentry programs are making legal work more attractive and sustainable and thus are reducing the incentive to return to crime. There are certain widely agreed-upon services that most ex-prisoners need, such as substance-abuse recovery or skills development; however, a program can customize its services by assessing its clients' specific needs. This may be achieved by means of surveys, focus groups or informal conversations. In Washington, CSOSA stressed the need for its mentor trainees to listen to participants' needs; in Jacksonville, Operation New Hope had workers pick up their checks at the office, so as to stay abreast of their circumstances and needs. Clearly, a program's funding influences its ability to provide services such as those described above. The first (ongoing) step is to assess clients' needs for services and then to fulfill the most critical needs in-house or by establishing partnerships with outside agencies that have complementary missions.

\section{STAFFING}

In staffing, reentry programs should mix "compassion and competence," as Rev. Isaac puts it. To do so requires hiring people with appropriate skills, hiring ex-prisoners when feasible and providing staff-development activities. Programs sometimes hire from the heart and not enough from the head. Reentry work requires good intentions, but it also requires specific skills and characteristics. Excellent communication skills, 
honesty, firmness, a nonjudgmental attitude, professionalism, salesmanship and vision were all cited as important qualities for people working in the reentry field. Also, hiring ex-prisoners is essential to building trust and responsiveness. Program participants may be more likely to trust and identify with program staff-especially those they come into contact with most, such as case managers - who are also ex-prisoners. Ex-prisoners can also help design a program that responds to their needs and perspectives in a way that an "outsider" might not consider. In Washington, ex-prisoners proposed the term "life coach" instead of "mentor" since the latter term made them feel diminished. Having ex-prisoners on staff also sends the message that participants are active and empowered in the program, not simply "objects" of a social service. But, as Rev. Isaac in Washington cautions, programs should take care to bring ex-prisoners on staff only after they have had sufficient time to stabilize in their lives and their sobriety; in his experience, this usually means 18-24 months after a person completes his or her sentence. Recently released ex-prisoners may have the passion but not the abilities required to do reentry work and only jeopardize the stability and security that program participants need. All staff-ex-prisoners or not-benefit from staff-development activities, such as trainings in ex-prisoners' needs, computer skills or other relevant areas. Program staff may complement one another but will almost inevitably have differences as well. Such conflicts may be complicated in the case of interracial partnership, such as in Operation New Hope. Building trust within the organization-such as through staff retreats, facilitated workshops and internal communications-can help make the program more effective for the people it serves.

\section{LEADERSHIP}

Faith-based reentry programs need leaders who can navigate the religious and secular spheres. Faith played a key role for all three programs. Their leaders were motivated by a religious sense of charity and justice. Life coaches in Washington were recruited from churches, and mentors in Jacksonville were clergy. All three organizations tended to take a broadly religious, or holistic, view on participants. As important a role as faith played, the programs often operated in the secular sphere, such as with foundation or corporate funders, government agencies or social service organizations. In other words, these programs drew heavily on the resources of both spheres and also had to follow the traditions and guidelines of each. For example, Rev. Isaac expressed himself in religious terms in the churches where he recruited mentors; he used more programmatic language when documenting ERCPCP's work to funders. To navigate successfully within and between these two spheres, the three programs in question had to draw on skilled leaders. Rev. Isaac in Washington is an ordained minister with more than 20 years of experience in city-government finance. In Jacksonville, Kevin Gay and Rev. Garland Scott teamed up to garner support and resources in the mostly white business community and the mostly African American community that Operation New Hope serves. And in Washington, the government agency CSOSA assembled a Faith Advisory Council to inform its work. In these and other ways, organizations made sure that secular, programmatic demands did not squelch the religious faith that fueled their work but rather enabled their faith to have an impact. 


\section{EXTERNAL RELATIONS}

A reentry program needs to work with others in the community-local government, the criminal justice system, community organizations, churches and employers-to maximize its effectiveness. Representatives from any of these sectors may be invited to serve on an advisory board or board of directors for the reentry program to strengthen their ties. The work of Operation New Hope, Second Chance and ERCPCP points to lessons about how to build and maintain those relationships.

\section{LOCAL GOVERnMENT}

Government agencies and politicians can be valuable partners for reentry programs. In Memphis, Mayor Herenton exercised substantial political will to get the Second Chance program up and running. He was able to do so because he was a highly skilled and popular third-term mayor. But even the most nascent program can learn from his case. It was constituents, ex-prisoners and their families, who told him of their plight and asked for help. Herenton says this was not a targeted campaign to get him involved in reentry work; nonetheless, it is an object lesson in how to garner support for a particular issue. Once he had decided to launch Second Chance, Herenton maneuvered politically in a way that is instructive for anyone hoping to start a reentry program. He anticipated arguments against the program and answered those challenges when he rolled it out. Not all programs need political support to get started-all it took in Jacksonville was a couple of committed staff with a good idea—but political support may help them expand. Operation New Hope garnered the awareness and support of some local politicians, which enabled it to get more funding and rise to national prominence. Organizations should weigh the pros and cons of seeking the support of the public or politicians. A fledgling program may be harmed by too much public scrutiny too early in its development, or it may become burdened by government bureaucracy or reporting requirements. On the other hand, a reentry program might need the support of a key politician to advance its agenda. Whatever the case, an organization should assess the political climate, its own needs and how the one might support the other.

\section{Criminal Justice System}

Judges, parole officers, correctional institutions and others can all help programs serve ex-prisoners and the communities to which they return. In Memphis, criminal court Judge McLin ordered parolees he supervised to participate in Second Chance. In Washington, CSOSA — and through it its lead agencies, like ERCPCP—worked in collaboration with the main correctional facilities to start the mentor relationship well before prisoners' release, which eased the transition back into society. In Jacksonville, Operation New Hope began a relationship with the sheriff's office, which flourished into a full-fledged partnership. REENTRY PROGRAMS AND THE CRIMINAL JUSTICE SYSTEM CAN HELP EACH OTHER FILL THEIR SHARED MISSIONS OF REDUCING CRIME AND RECIDIVISM. In order to develop these relationships, reentry programs should conduct research on the criminal justice system to determine any possible areas for collaboration, prepare a presentation of 
their work for people in criminal justice, seek out people in criminal justice whose interests are aligned with those of the reentry program, and explore options for cooperation with those who become friends of the program.

\section{COMMUNITY ORGANIZATIONS}

Community partners helped programs in these three cities to serve ex-prisoners and their communities. Operation New Hope found that many participants had trouble keeping a job because of substance-abuse problems, so it engaged with a recovery service organization. Second Chance partnered with its local WIN to provide soft-skills and vocational-skills training to program participants. ERCPCP worked with the Jobs Partnership to recruit employers who would hire ex-prisoners. As they have evolved, some programs, like Operation New Hope, have found it more effective to bring all their services in-house; but for fledgling organizations, mutually beneficial partnerships help to fill out all necessary program components. Aside from providing services, community organizations can also be a source of referrals. Reentry programs should bear in mind not just what they get out of a relationship with a community partner, but what they give to it and how they can help those partners fulfill their missions. For example, Second Chance is a source of qualified workers for local companies, and that supports the WIN's mission of serving workers and employers alike. An additional benefit accrues to reentry programs that formally partner with other community organizations; many foundations favor grant applications for collaborative projects. Collaborations can present their own difficulties, but they can also present new opportunities for partners to fulfill their own missions in a way that is appealing to many funders.

\section{CHURCHES}

Churches are a great source of experience, wisdom, relationships and volunteers. Of the three organizations profiled here, only one-ERCPCP_had a formal mentoring component before becoming part of Ready4Work. Their experience yields several insights for other programs. First, gather all information and create a system of communications to facilitate the relationship. Pastors who attended ERCPCP's meetings filled out registration forms with complete contact and other information, making communication easier. Second, anticipate and address churches' concerns. One pastor in Washington spoke for others when he expressed trepidation at getting involved with ex-prisoners. Whether it's simply a matter of time and resources or concerns over safety, churches may have their worries about this field of work. By providing ample orientation, information and time for questions, reentry programs can make churches their full partners. Third, make room for churches to help create the program, instead of just signing on to it. ERCPCP's Seven-Point Plan was created by participating pastors, who as a result felt more buy-in than had they just signed on to a preexisting program. Fourth, provide training and support. As ERCPCP's Rev. Isaac says, just because someone's faith mandates this sort of work does not mean he or she is personally suited to it. Church volunteers can play any one of a number of roles, apart from just mentoring. Place volunteers in positions appropriate for them, and provide ongoing training and support so they can do their jobs well. CSOSA's training covered the fundamentals, and Rev. Isaac and his staff were always available to mentors for ongoing support. 


\section{EMPLOYERS}

Many reentry programs start with the purpose of serving ex-prisoners and the communities they come home to. But in order to help ex-prisoners find and keep livingWage jobs, REENTRY PROGRAMS NEED TO DEVELOP STRONG RELATIONSHIPS WITH EMPLOYERS, AND THAT MEANS TREATING THEM AS CUSTOMERS. The example of Second Chance is especially instructive here. Yalanda McFadgon observes, "We're selling a product-exfelons-that nobody wants." She uses a variety of selling strategies. She breaks down employers' preconceptions about ex-prisoners by personalizing their lives and struggles. She emphasizes that hiring her trained, prescreened, case-managed workers is good for the bottom line. She gives employers control in the process by opening program participants' case files to them and allowing them to rule out any candidate or even any category of felony conviction. She matches workers with jobs according to their interests, skills and temperaments; this makes for a happy employee and, hence, a happy employer. Finally, she maintains her relationships with employers through calls, cards and personal visits so they will want to continue to hire Second Chance participants. On the participant side, she provides thorough training and enforces a zero-tolerance policy on program violations, so all the workers she sends out are top quality. The result is a diverse set of satisfied employers who will continue to hire ex-prisoners.

\section{CONTINUING to PiOneER}

Operation New Hope, Second Chance and the East of the River Clergy-PoliceCommunity Partnership raised awareness about the importance of reentry; they experimented with program strategies; they prayed for guidance and wisdom; they made friends in the worlds of business, criminal justice and social service; they built organizations and did the nuts-and-bolts work required to welcome ex-prisoners back into their communities as contributing members.

These organizations and others like them made the Ready4Work initiative possible. Their hard work inspired and educated policymakers, funders and other practitioners to take reentry more seriously. And now Ready4Work has advanced the reentry movement with funding, relationships, technical assistance, information-sharing and documented outcomes. Even with all that Ready4Work has accomplished since its founding in 2002, the pioneering spirit that these home-grown organizations displayed in their early days is still vital to the movement's continuing success.

Building a movement is an ongoing process. Just as in the years before Ready4Work started, the reentry movement still needs people who take initiative, experiment, respond to local needs, draw on available resources and build new relationships. It still needs pioneers. Those pioneers can come in the form of foundations that provide funding, lawmakers who create policy to support reentry, correctional institutions that team up with outside organizations to ensure a successful transition for prisoners, employers that hire ex-prisoners, community organizations to provide wraparound services and reentry programs that assemble these people and resources. This growing movement can welcome ex-prisoners back into their communities to live satisfying, productive lives. 


\section{Summary of Recommendations}

\section{Internal Components}

\section{Model}

- Assess the needs identified in the organization's mission and the resources in and outside the organization

- Design program model that applies resources to meet needs.

- Balance program capacity with program demand, such as by accepting only as many participants as the program can manage.

\section{Structure}

- Outline all roles and responsibilities to be fulfilled in order to serve the mission.

- Create an organizational structure that ensures those roles and responsibilities are filled.

- Facilitate communication among staff, board and other personnel.

\section{Services}

- Assess ex-prisoners' service needs through surveys, focus groups or conversations.

- Arrange for services to ex-prisoners, whether inhouse or by partnering with outside providers.

- Arrange for career-enhancement opportunities for participants, based on their interests and information about the labor market derived from workforce development organizations, government agencies or employers.

\section{Staffing}

- Hire from the head, not just from the heart. Reentry work requires skills, not just good intentions.

- Hire ex-prisoners who are stable in their recovery and reintegration to build trust and responsiveness with participants.

- Conduct staff development activities, such as trainings, on-line skills development, retreats, etc

\section{Leadership}

- Bring aboard leaders who can navigate the religious and secular spheres.

- Recruit advisors or committees to help bridge the religious and secular spheres, and bring resources to bear in support of the program's mission.

- Bear in mind the religious and secular demands on the organization and possible conflicts between them.

\section{External Relationships}

\section{Local Government}

- Assess the reentry program's needs and how local government might help.

- Assess the risks of political or government support, such as reporting requirements or political entanglement.

- Anticipate arguments against reentry programs and prepare a case in favor.

\section{Criminal Justice System}

- Consider the organization's needs and how the criminal justice system might assist.

- Research the programs and players in the criminal justice system, with an eye to possible collaborations. Look for common goals.

- Develop allies in the criminal justice system for support and in a possible advisory role.

\section{Community Organizations}

- Partner with community organizations for referrals and to provide services to program participants.

- Seek out ways the reentry program may support the missions of community partners.

- Consider creating formal partnerships with community organizations for collaborative grant applications.

\section{Churches}

- Gather information from interested churches, and create a system of communications.

- Anticipate and address churches' concerns about working in the reentry field.

- Make room for churches to help create the program, instead of just signing on to it.

- Provide ongoing training and support to pastors and volunteers from participating churches.

\section{Employers}

- Treat employers as customers.

- Break down employers' preconceptions about ex-prisoners by personalizing their lives.

- Emphasize that hiring trained, prescreened, case-managed workers is good for business.

- Match workers with jobs according to their interests, skills and temperaments.

- Maintain relationships with employers through cards, calls and personal visits. 


\section{ENDNOTES}

1 US Bureau of Justice Statistics, annual report 2003.

2 US Bureau of Justice Statistics, annual report 2003. The number of people leaving incarceration has continued to rise since 2002, to some 750,000 (including juvenile offenders) per year as of 2006 .

3 "Recidivism of Prisoners Released in 1994," by Patrick Langan and David Levin. Bureau of Justice Statistics, 2002. Cited in When the Gates Open, by Joshua Good and Pamela Sherrid, October 2005.

4 The Ready4Work initiative is comprised of 11 adult sites and 6 juvenile sites. The adult sites are in Chicago, Detroit, Houston, Jacksonville, Los Angeles, Memphis, Milwaukee, New York City, Oakland, Philadelphia and Washington, DC. The juvenile sites are in Boston, Brooklyn, Camden, Houston, Los Angeles and Seattle. For more information on these programs, go to www.ppv.org. See also the reports When the Gates Open and Just Out, cited in footnote 5.

5 When the Gates Open (October 2005) describes the emergence of Ready4Work. Just Out, by Linda Jucovy (February 2006), examines the early implementation of Ready4Work and reports on emerging best practices in four key program areas. Ready4Work In Brief (September 2006) explores interim outcomes from the initiative. Available at www.ppv.org.

6 Gavan, Barbara. "Rising from the Ashes: Springfield's Historic District Returns to Life." Florida Times Union, April 14, 2005.

7 Bauerlein, David. "Homes: Property Values on the Rise." Florida Times Union, September 9, 2002, B-1.

8 Weathersbee, Tonyaa. "Mean Streets Nothing New for Pastor," Florida Times Union, May 10, 1998.

9 Dr. Andrew Billingsley interview with Kevin Gay and Garland Scott.

10 Maraghy, Mary. "President Taps Duval Effort as National Model: Jobs Program for Ex-Cons Reflects Faith-Based Goals." Florida Times Union, June 29, 2002.

11 Services for Ex-Offenders: A Report to the Citizens of Jacksonville. Jacksonville Community Council Inc. Spring 2001. Available at www.jcci.org/projects/reports/2001_services_exoffenders.aspx. Quotes are from pages 2, 9, and 16.

12 Dr. Andrew Billingsley interview with Kevin Gay and Garland Scott.

13 Maraghy, Mary. "President Taps Duval Effort as National Model: Jobs Program for Ex-Cons Reflects Faith-Based Goals." Florida Times Union, June 29, 2002.

14 According to the Tennessee Department of Correction, more than 12,000 ex-felons were released into the state in fiscal year 2000-01. The Annual Report for that year does not show which counties they were released into, but judging by population and the conviction rates in Shelby County, one fifth or more of the total people released would likely go there. See TDOC Annual Report for fiscal year 2000-01. Available at www.state.tn.us/correction/planning/annualrpt.html.

15 Horatio Alger Award. www.horatioalger.com/members/member_info.cfm?memberid=her88.

16 Dries, Bill. "Herenton Urges Jobs for Ex-Felons." Memphis Commercial Appeal, April 18, 2000. 
17 "Reentry Sunday" became "Reentry Weekend" in 2003, to better integrate other faith practices, including Seventh Day Adventists who worshipped on Saturday and Muslims on Friday. The event was expanded to "Reentry Week" in 2004.

18 Wagner, Arlo. "Churches Help Reform Parolees." The Washington Times, January 9, 2002.

19 The number of people under CSOSA's supervision at any given time has continued to rise; Associate Director Cedric Hendricks says in 2006 the figure was roughly 15,000.

20 Broadway, Bill. "A Spiritual Path to Freedom: D.C. Agency Urges Congregations to Help Inmates Make Transition." The Washington Post, January 12, 2002.

21 Mauer, Marc and Tracy Huling. "Young Black Americans and the Criminal Justice System: Five Years Later." The Sentencing Project, October 2005. Available at www.sentencingproject.org/ pubs_08.cfm.

22 CSOSA Fact Sheet: Re-Entry System. CSOSA Office of Legislative, Intergovernmental, and Legislative Affairs, July 2002. Available at www.csosa.gov.

23 CSOSA website, www.csosa.gov.

24 Statement by Paul A. Quander, Jr., Director, Court Services and Offender Supervision Agency for the District of Columbia, before the United States House of Representatives Committee on Government Reform, February 2, 2005. Available at www.csosa.org/Olipa/testimony/ house_reentry_020205.pdf.

25 Cauvin, Henri, "Helping Inmates Find Their Way Home: Program Pairs Ex-Convicts with Houses of Worship." The Washington Post, February 12, 2004.

26 McGinnis, Joyce. "First Year of Partnership Brings Hope, Help to D.C. Offenders Coming Home From Prison." CSOSA/Faith Community Partnership newsletter, April 3, 2001.

Available at www.csosa.gov.

27 Once it was funded by Ready4Work, ERCPCP used Ready4Work resources only for people in the age bracket designated by the program's guidelines. 


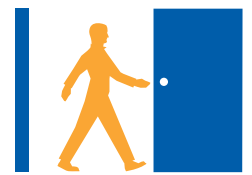

Ready 4 Work

Ready4Work is an initiative of Public/Private Ventures

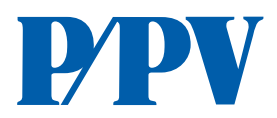

\section{Public/Private Ventures}

2000 Market Street, Suite 600

Philadelphia, PA 19103

Tel: (215) 557-4400

Fax: (215) 557-4469

New York Office

The Chanin Building

122 East 42nd Street, 42nd Floor

New York, NY 10168

Tel: (212) 822-2400

Fax: (212) 949-0439

California Office

Lake Merritt Plaza, Suite 1550

1999 Harrison Street

Oakland, CA 94612

Tel: (510) 273-4600

Fax: (510) 273-4619

http://www.ppv.org 